\title{
RECENT REGULATORY AND LEgISLATIVE DEVELOPMENTS OF INTEREST TO OIL AND GAS LAWYERS
}

\author{
GORDON M. NETTLETON ${ }^{*}$
}

This arficle examines recent regulatory and legislative developmenls relevant to oil and gas lawyers. Regulatony decisions of the federal National Energy Baard and the Alberta Energy and Uilities Board receive parlicular focus, as well as legislative developments in British Columbia and Saskatchewan. The article concludes with a discussion of recent guidelines, policies and directives.
Cet article porte sur les derniers développements réglementaires et législatifs intéressant les avocats specialisés dans le domaine pitrolier et gazier. Une attention particuliere est accordée atux décisions réglementaires de l'Oblce national de l'énergie et du Alberia Energy and Uilities Board ainsi qu'au développemenis législatifs en Colombie-Brirannique et en Saskatchewan. Cel arlicle se rermine sur une discussion des récentes lignes de conduite, politiques et directives.

\section{TABLE OF CONTENTS}

I. INTRODUCTION . . . . . . . . . . . . . . . . . . . . . . . . . . 247

II. REGULATORY DEVELOPMENTS $\ldots \ldots \ldots \ldots \ldots \ldots \ldots \ldots \ldots \ldots \ldots$

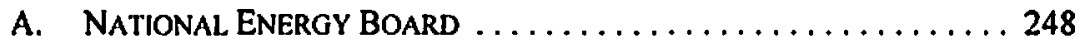

B. AlberTA ENERGY AND UTILITIES BOARD . . . . . . . . . . . 262

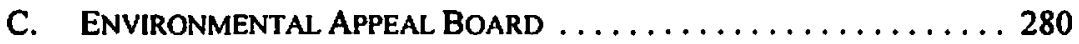

III. LEgISLATIVE DEVELOPMENTS $\ldots \ldots \ldots \ldots \ldots \ldots \ldots \ldots \ldots \ldots \ldots$

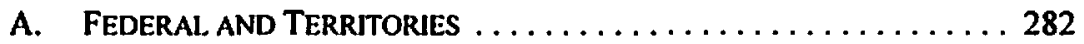

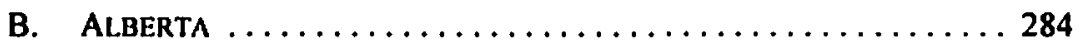

C. British ColUMBIA ..................... 286

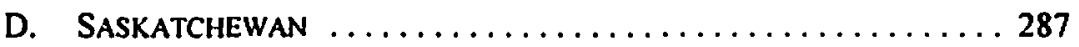

E. Guidelines, Policies and Directives $\ldots \ldots \ldots \ldots \ldots \ldots$

\section{INTRODUCTION}

This article discusses recent regulatory and legislative developments affecting the oil and gas industry. Section II of the article discusses significant decisions made by regulatory tribunals over the past year, with the focus being on decisions rendered by the National Energy Board (NEB) and the Alberta Energy and Utilities Board of Alberta (AEUB). Section III highlights legislative amendments made over the past year, again with emphasis on the federal and Alberta jurisdictions.

The purpose of this article is to report and provide commentary only on significant regulatory developments that may be of interest and assistance to energy law practitioners. As a result, this article is not an exhaustive report of all regulatory developments.

Osler, Hoskin \& Harcourt LLP, Calgary, Alberta. The author gratefully acknowledges the assistance of James H. Smellie, partner and Annamaric Bergen, Legal Information Specialist, Osler, Hoskin \& Harcourt LLP. The views expressed are those of the author and do not represent the position of Osler, Hoskin \& Harcourt LLP or its clients. 


\section{Regulatory Developments}

\section{A. National EnERgy BoARD}

The National Energy Board (NEB) is responsible for the regulation of Canada's interprovincial and international oil and gas pipelines. As well, the NEB has jurisdiction over the approval of Canadian oil and natural gas exports and imports. This year, the NEB issued significant decisions in the traditional areas of pipeline tolling and applications for approval to construct and operate new pipeline facilities. The less traditional area (at least in recent times) of natural gas export order requirements was also revisited by the NEB.

\section{TOLL DECISIONS}

\section{a. Reasons for Decision In the Matter of TransCanada PipeLines Limited Fair} Return Application dated 6 June 2001 in respect of Cost of Capital Matters ${ }^{1}$

For the first time in over eight years, the NEB rendered a substantive decision on the method and level of return TransCanada PipeLines Limited (TransCanada) should be allowed to earn and recover through rates.

In 1994/95, the NEB convened a generic proceeding that determined the capital structure, debt and equity components and the methodology used to determine the return on equity level for the largest NEB regulated pipelines, including TransCanada. The formula approved by the NEB in its Reasons for Decision In the Matter of TransCanada PipeLines Limited, Westcoast Energy Inc., Foothills Pipe Lines Lid., Alberta Natural Gas Company Lid., Trans Québec \& Maritimes Pipeline Inc., Interprovincial Pipe Line Inc., Trans Mountain Pipe Line Company Lid. and Trans-Northern Pipeline Inc. in Respect of Cost of Capital ${ }^{2}$ was based on an equity risk premium methodology and was applied to a hypothetical low-risk benchmark pipeline. Individual pipeline companies, such as TransCanada, were compared to the established benchmark and adjustments were made to take into account unique business risk features. Thereafter, the RH-2-94 formula has been adjusted annually to take into account changes in prevailing yields on long-term Canada bonds.

The RH-2-94 formula initially resulted in a generic return on equity of 12.5 percent for 1995. However, due to subsequent significant reductions in bond yields, the RH-2-94 formula has, in more recent years, resulted in much lower return levels. In 2002, the RH-2-94 formula yielded its lowest level of 9.53 percent.

Given this level of return, the pipeline industry has expressed significant concerns. The reduced levels, coupled with unprecedented structural changes in the pipeline industry itself (in particular, the increase of "pipe on pipe competition" created by the start up of the Alliance and Vector Pipeline Systems and supply risk stemming from the maturing nature of the Western Canadian Sedimentary Basin), prompted TransCanada to take regulatory action. On 6 June 200I, an application was made to the NEB to review and vary RH-2-94 with the 
underlying objective of no longer having the RH-2-94 formula apply to rates charged on TransCanada's Mainline System.

In place of the RH-2-94 formula, TransCanada proposed that the NEB either determine its appropriate cost of capital using what is referred to as an "after tax weighted average cost of capital"' (ATWACC) method or, in the alternative, using a more conventional method such that return on equity would be established at 12.5 percent on a deemed equity component of 40 percent. If approved, TransCanada's resulting cost of service to be recovered from toll payers will increase by $\$ 265$ million.

As expected, significant opposition was raised by those most affected by the proposed increase in rates, including the Canadian Association of Petroleum Producers, the Industrial Gas Users Association, Centra Gas Manitoba Inc. and several natural gas marketers/shippers on the TransCanada system, including Mirant Energy.

The main issues in this case were whether the $\mathrm{RH}-2-94$ formula remained an appropriate means to determine the cost of capital for the TransCanada Mainline System; and, if not, what other methods were appropriate substitutes. The main focus, of course, was whether either ATWACC or the proposed 12.5 percent return on a 40 percent deemed equity structure resulted in just and reasonable tolls.

The NEB found that the rate of return on common equity resulting from the RH-2-94 formula should continue to apply to TransCanada's Mainline System. The effect of this decision was that TransCanada's return on equity was established at 9.61 percent for 2001 and 9.53 percent for 2002. With respect to capital structure, the NEB found that the level of business risk facing TransCanada's Mainline System had increased since the RH-2-94 Decision, primarily due to pipe-on-pipe competition and supply risk. However, the NEB found that this risk remained low, that TransCanada's financial position remained strong, and that TransCanada's ability to attract capital was not in jeopardy. These conclusions resulted in the NEB increasing TransCanada's deemed common equity component from 30 percent to 33 percent, considerably shy of the 40 percent requested by the company in its alternative claim.

RH-4-2001 is important for several reasons. First, the proceeding will be remembered for its determination of what is meant by the "fair return standard" applied in determining a pipeline's cost of capital. The decision outlined the legal framework and analysis that the NEB uses when it considers this complex issue. The fair return standard is comprised of three primary principles. First, a reasonable rate of retum must be comparable to the return available from the application of the invested capital in other enterprises of like risk. Second, it must enable the financial integrity of the regulated enterprise to be maintained and permit incremental capital to be attracted to the enterprise on reasonable terms and conditions. Third, it must achieve faimess from the viewpoint of customers, as well as present and prospective investors. 
The decision also made clear that the analysis used to consider these principles is focused on the individual business and financial risks of the applicant pipeline company. Under the business risk heading, four areas were considered: market risk; supply risk; regulatory risk; and operational risk. With respect to financial risk, the analysis focused on the comparable investment standards, capital attraction objectives and other investment perspectives.

Second, there has been a growing trend for regulators to use generic methods or formulae for determining cost of capital. Similar but not identical formulae have been adopted by utility regulators in British Columbia, Manitoba and Ontario. The NEB was among the first to go this route. However, having implemented such a formula, the issues that were tested in this proceeding are: how long will the formula last before it needs to be adjusted; and whether the formula approach is the only means by which cost of capital can or should be determined for an individual pipeline company. In other words, does the generic formula approach, once adopted, preclude other methods from being used that may also satisfy the statutory just and reasonable toll standard?

Third, the decision is important given its consideration of the ATWACC method for determining cost of capital. There is a growing trend among utility applicants to have regulators consider and approve this method. While the NEB is now added to the list of those who have chosen not to do so, the methodology itself was not rejected in its entirety. Rather, TransCanada's specific proposal was not demonstrated as offering significant advantages over the existing RH-2-94 formula.

Fourth, while the legal framework and analytical approach are described in the NEB's reasons, an issue which remains unclear is the threshold that must be met in order to depart from the RH-2-94 formula. Review and variance decisions have historically been dependent upon applicants showing, inter alia, changes in circumstances and/or new facts. Indeed, this is what TransCanada attempted to show through evidence of fundamental changes occurring in both capital markets, as well as TransCanada's business and operating environments. As the NEB was obviously not persuaded with what was presented, the question remains: what will it take for an applicant to achieve the intended result? The impression left by this decision is that simply showing that an alternative method results in just and reasonable tolls will not be sufficient. Rather, the decision implies that there is a need to show that the alternative method is superior to the existing method or that the formula has become antiquated and results in unjust and unreasonable tolls. In either case, these are very high thresholds.

Fifth, RH-4-2001 has at least implicitly reconfirmed the NEB's desire to have issues resolved by way of settlement outside of its hearing process. In the author's view, settlement now remains the only viable approach for a pipeline company to achieve with certainty the objective of no longer having the RH-2-94 formula apply to rates. However, though settlements may be preferable, significant realities, complexities and indeed impossibilities may exist in achieving them, given the multiple interests that stakeholders bring to the negotiation table. Further, a "negotiated result" that departs from the RH-2-94 formula is now arguably even tougher for any pipeline company to achieve, given the strong reasons provided by the NEB to maintain the RH-2-94 formula. For those on the other side of the negotiation table to pipelines, $\mathrm{RH}-4-2001$ arguably provides an opportunity to extract something more in order to support dispensing with the RH-2-94 formula. 
At the end of the day, RH-4-2001, as well as the subsequent RH-R-I-20024 review and variance decision discussed immediately below, suggest that the NEB is not likely to alter its use of the RH-2-94 formula at present. A more compelling case is required - perhaps one that involves the active participation of more than one regulated pipeline affected by the formula. Those up to the task of seeking a successful review of the RH-2-94 formula must go back to the drawing board to ascertain what more is needed.

b. Reasons for Decision in the Matter of TransCanada PipeLines Limited Application dated 16 September 2002 Requesting a Review and Variance of National Energy Board RH-4-200/ Cost of Capilal Decisions

In September 2002, TransCanada filed an application to have the NEB review and vary RH-4-2001. The application cited over thirty-six alleged errors committed by the NEB. These errors related to:

- breaches of the NEB's legal obligation to apply the fair return standard;

- improper application of the comparable investment, capital attraction and financial integrity standards;

- misinterpretation of the ATWACC proposal;

- continuation of the application of the RH-2-94 formula based on irrelevant considerations; and

- breach of the duty of fairness by failing to provide adequate reasons for many of the NEB's decisions.

Notwithstanding the depth of TransCanada's review application, it was ultimately rejected on all accounts. The reasons for reaching this result are analyzed below.

\section{(i) Standard of Review}

The decision provided a useful discussion of the general standard of review used by the NEB for applications made pursuant to s. 21 of the National Energy Board Act, ${ }^{\circ}$ and it is now clear that the standard is one of correctness. One interesting feature of this result was how the NEB applied this objective standard to the determination of a subjective issue, namely, the level of return that a pipeline company is allowed to earn. This is a question that, in large measure, depends upon the interpretation given to expert opinion evidence.

The approach taken by the NEB was one that considered whether the panel in the first instance had fairly addressed its mind to the issues involved and weighed the evidence placed before it in a fair manner. Application of the correctness standard in the review and variance process is not one that provides the opportunity to re-weigh and reassess the evidence. Rather, the focus is on whether there is a demonstrable error, such as reliance upon irrelevant evidence, non-consideration of all relevant evidence or application of inappropriate tests or factors - demonstrating that the decision was made in an arbitrary manner or that the NEB did not provide adequate reasons for its decision. 
The decision is also useful to understand how the NEB approaches its obligation to provide regulated pipeline companies with a fair return on capital employed. One of the primary errors alleged by TransCanada was that the NEB "is required by law to apply the comparable investment, financial integrity and capital attraction standards to determine a fair return for the Mainline." After reviewing the applicable jurisprudence, the NEB disagreed with this characterization. ${ }^{8}$ Instead, the NEB found that its obligation was to establish tolls using the broader "just and reasonable" standard and, in so doing, it was not bound to a particular approach. While the standards of comparable investment, capital attraction and financial integrity that determine a fair retum were found to be relevant and indeed prerequisites to the just and reasonable threshold, the NEB also found that the interests of consumer/ratepayers must be considered equally in this inquiry.

Applying this approach to the facts at hand, many of TransCanada's arguments were simply characterized as taking issue with the appropriate weight that the NEB had ascribed to the evidence, as opposed to an erroneous mishandling of the evidence itself. Since it was found that the panel, in the first instance, had considered the standards of comparable investment, capital attraction and financial integrity before approving the use of a return methodology, TransCanada had not sufficiently demonstrated that errors as to the correctness of the decision had in fact been made.

While it is now clear that the correctness standard applies to NEB review and variance applications and that the NEB will approach questions of rate of return broadly under the guise of the "just and reasonable" standard, what remains unclear is whether the RH-2-94 formula can ever be successfully reviewed by a single applicant.

Given the result of RH-R-1-2002, arguably, the difficulty is that the decision now entrenches the RH-2-94 formula to the point where it is unlikely for another rate of return methodology to ever be placed before the NEB in a singular contested situation. The NEB has applied the "correctness" standard of review to require any applicant seeking to implement a different return methodology to demonstrate first that the existing method effectively creates unjust or unreasonable tolls or is more complex, less certain, or less transparent than what the applicant is proposing. Given the systemic use of the RH-2-94 formula and the recognition that it withstands the test of significant changes in financial markets and competitive pipe-on-pipe situations, even if a new method were demonstrated to have equal value, it is not clear that such a method would be found to be a suitable replacement. Given this, one must question whether (or why) it would be likely for any single applicant to test these waters again, given that the likelihood of success would seem remote.

- Supra note 5 at 6 [emphasis added].

- Ibid. at 7-12. Cases considered were Northvestern Uhilities Limited v. City of Edmonton, [1929] S.C.R. 186: Trans.Mountain Pipeline Company v. National Energy Board, [1979] 2 F.C. 118 (C.A.); British Columbia Hydro and Power Authority v. Westcoast Transmission, [1981] 2 F.C. 646 (C.A.); Bluefield Watenvorks \& Improvement v. Public Service Commission of West Virginia, 262 U.S. 679 (1923): Federal Power Commission v. Hope Natural 320 U.S. 591 (1944). 
However, perhaps that is the policy point of the decision. In RH-2-94, the NEB set out to create one single, certain, transparent and methodical approach to determine return levels for each of its largest pipeline companies, allowing it to do away with regulatory process/oversight and fulfilling the objective of creating regulatory efficiency.

Allowing one party to challenge the RH-2-94 formula's prudency and reasonableness in a contested setting successfully arguably puts at risk the future regulatory efficiencies that would be achieved by continued use of a generic formula method. Said another way, it would likely cause other pipeline companies to at least consider taking the same litigation route. Arguably, this would send a troubling policy signal, one that might be interpreted as suggesting that the NEB wants to get back into the business of determining rates of return on a case-by-case basis using a variety of methods and approaches. However, at law, one may at least question whether the NEB is fettering its discretion by issuing both generic decisions and decisions that become extremely difficult to challenge.

Perhaps a more simple perspective of RH-R-1-2002 concerning what an applicant must demonstrate to change the RH-2.94 formula is this: since the RH-2.94 formula was determined by way of an NEB initiated generic proceeding, one in which the NEB required the participation of all major pipeline companies, arguably it is only a similar type of proceeding that can be used to review and vary the decision taken.

It should not be forgotten that TransCanada was effectively alone in seeking a change to the RH-2-94 formula. Clearly, the participation of those pipelines who had been involved in RH-2-94 (as well as those proceedings formed since) could have addressed one of the most significant deficiencies cited by the NEB, namely, that TransCanada had not provided an adequate comparison of the relative pipeline business risks and the impacts on cost of capital for other NEB regulated pipelines. While TransCanada argued that this was an unattainable evidentiary standard, given the need to access third party information, one would expect that this standard could be met through a generic proceeding that requires the involvement of others. $^{10}$

- Arguably, if Parliament had desired the NEB not to "be in the business" of determining rates of return on methodologies other than a prescribed generic formula, legislation to this effect would have been put in place. Such legislation has been seen in other jurisdictions. For example, under the older New Brunswick Public Unilities Acs. R.S.N.B. 1973, c. P.27, New Brunswick Power was allowed to increase rates annually by 3 percent or by the Consumer Price Index without seeking regulatory approval or justification for such increases. This form of price cap regulation precluded inquiry into the reasonableness of rates charged by the utility, including rates of return.

It is important to note that RH.2.94 was initiated by the NEB itself and required the participation of all of the major NEB regulated pipelines. In order for a review and variation of the RH-2-94 formula to occur, one would think it necessary to convene a generic review proceeding to achieve this result. This was not the case in RH-4-2001, as this application was specific to TransCanada. Although other regulated pipelines were able to intervene in this proceeding, none took an active role. One likely reason for this is that several pipeline companies (i.e. Enbridge Inc.. TransMountain Oil) are subject to negotiated settlements, the terms and conditions of which may arguably be breached if the pipeline company takes steps to initiatc or panticipate actively in a regulatory proceeding commenced by another pipeline intended to vary the RH-2-94 formula. One possible way to overcome this lack of active participation would be for the NEB once again to initiate a "generic" review proceeding that requires the participation of all regulated pipelines. 
Based on the foregoing, the threshold necessary to vary the RH-2-94 formula remains uncertain in many respects. Based on what is known, the threshold appears to be very high and perhaps unattainable by one party in the absence of substantive or unequivocal evidence that shows that the formula results in unjust and unreasonable tolls. Until such time as the NEB decides to reconvene a generic proceeding to determine how fair return should be determined, assessing all methods on a similar basis and threshold, it is unlikely that there will be any change.

\section{iv. Adequacy for Reasons for RH-R-1-2002}

There is a developing body of common law on the need for administrative tribunals to provide sufficient or adequate reasons for their decisions. "The argument is that it is an error of law if reasons are not adequate to allow meaningful appellate review of the correctness of a decision. Inadequate reasons, therefore, lead to a breach of the tribunal's common law duty of fairness.

In RH-R-1-2002, the NEB accepted that it is under an obligation to provide adequate reasons, when reasons are in fact given. ${ }^{12}$ However, the NEB held that it is not "required to give reasons on each and every element of an argument presented, although those elements must be considered." Instead, the NEB held that "reasons must only make it clear that the NEB considered and weighed all of the evidence and established the grounds for the basis of the NEB's findings." ${ }^{14}$ Whether adequate reasons have been provided remains fact- or decision-specific. The issue essentially boils down to whether insight into the reasoning followed by the decision maker, including the factors used in considering the matter at hand, have been clearly articulated.

Here, the NEB justified the brevity of the views expressed by the initial panel by suggesting that it "discussed only those issues which, at least on the face of the record, appeared to have merit." Is As the initial panel was under no obligation to provide reasons for each and every element of the case, on the entirety of the decision, the reviewing panel found that adequate reasons had been provided.

On 21 March 2003, TransCanada sought leave to appeal RH-R-1-2002 to the Federal Court of Appeal. Two questions of law have been cited, namely, whether the NEB properly applied the fair return standard by including consumer interests; and whether the NEB fettered its discretion by the standard of review imposed upon the use of the RH-2-94 formula. Interestingly, inadequate reasons were not pleaded.

Baker v. Canada (Minister of Citizenship and Immigration), [1999] 2 S.C.R. 817.

Supra nole 5 at 31 .

Ibid. at 31, relying on SEJU Local 333 v. Nipawin Dissrict Staff Nurses Association, [1975] I S.C.R.

382 at 391 .

is $\quad$ bid. at 31 .

is lbid. at 33 . 


\section{FACILITIES DeCISIONS}

a. Reasons for Decision in the Matter of Westcoast Energy
Southern Mainline Expansion ${ }^{16}$

GH-1-2002 highlights the escalating importance of environmental and public relation challenges that applicants must be prepared to meet when new pipeline facilities projects are proposed in areas where public concern is expressed. While greenfield projects have traditionally raised public concems, there seems to be a growing trend towards increased public concern about non-greenfield projects that only involve modifications to existing compression or loops being added to existing infrastructure situated within existing rights-ofway. This at least seems to be so in specific regions of Canada, particularly British Columbia and southern Ontario. In $\mathrm{GH}-1-2002$ the added public concern item was the new and unique challenge facing both federal regulators and applicants in satisfying their legal obligations to consult with Aboriginal First Nations.

On 2 January 2002, Westcoast Energy (Westcoast) made application to the NEB pursuant to s. 52 of the $N E B A C t^{17}$ for a certificate of public convenience and necessity authorizing the construction and operation of its Southern Mainline Expansion Project (Project). Initially, the Project involved three main components: upgrades to compression facilities; installation of $89.5 \mathrm{kms}$ of 42 -inch outside diameter line pipe which would be installed in eight looping segments to its existing system; and installation of new custody transfer measurement facilities at the Huntingdon Meter Station at the British Columbia/Washington State international boundary. On 15 May 2002, Westcoast revised its application by eliminating two of the eight proposed loop segments and reducing the size of four others, such that the total length of new required line pipe was reduced to $54.6 \mathrm{~km}$. The revised application reduced the capital cost of the project from approximately $\$ 338$ million to $\$ 270$ million. The project would provide for additional capacity of approximately 5,656 thousand cubic metres per day $\left(10^{3} \mathrm{~m}^{3} / \mathrm{d}\right)$ or 199.7 million cubic feet per day (MMcf/d) to the Southern Mainline system. The change in scale was in response to an agreement reached between Westcoast and BC Gas Utility Ltd. (BC Gas Agreement) respecting a number of transportation, tolling and contractual issues.

The BC Gas Agreement removed any commercial intervenor issues concerning the application. The remaining intervenors were: stakeholders situated in areas where the new facilities were proposed to be constructed; a special interest group who claimed concerns over the inadequate study of potential cumulative environmental effects caused by the project, given the consequential development of downstream gas pipeline infrastructure and end-use gas development projects; and Aboriginal First Nation Groups concerned with the level of consultation undertaken by both the Westcoast and the NEB.

While neither stakeholder nor landowner concerns ultimately caused the Project to be modified in any significant way, this case is noteworthy for the increased efforts taken by the NEB to manage perceptional issues, create public awareness and enhance public participation 
in its proceedings. Due to the perceived level of public concern with the Project, the NEB hosted several public information sessions in advance of the actual hearing to familiarize the public with the NEB's operations, the application and the hearing process. Further, the hearing itself was divided into two phases and two separate locations (Chilliwack and Williams Lake) to allow local public participation in the hearing process. However, these steps were not without some cost to Project proponents. The NEB's formal regulatory process took approximately one year to complete from the date that the application was filed until $\mathrm{GH}-\mathrm{I}-2002$ was issued.

Turning to the topic of Aboriginal consultation, the issues of adequate applicant and Crown consultation were raised. Initially, Westcoast had not contacted all potentially affected First Nations prior to filing its final application. Additional consultative steps were required that resulted in commitments being made by Westcoast to prepare traditional land use surveys to ensure that the Project did not affect such lands. This approach satisfied all but one First Nation, namely, the Cheam Indian Band (the Cheam). Broader concerns about the overall impacts of the existing pipeline operating on and through traditional and sacred lands were raised by the Cheam. From the Cheam's perspective, Westcoast's consultations had not taken these concerns into account.

The Cheam also argued that a fiduciary duty was owed to it and that neither the federal government, the provincial government, nor the NEB had complied with that duty. ${ }^{18}$ The Cheam asserted that a duty to consult exists wherever Aboriginal rights and title could be affected, and that their rights and title were being compromised and put in jeopardy through the process brought about by the proposed Project. The degree of Aboriginal title infringement resulting from the Project, it was alleged, made it necessary for the Cheam to consent before the Project could proceed. Finally, the Cheam demanded a share of the economic benefit from the Project to ensure proper compensation was provided for all lands affected by the Westcoast system.

Given the recent judicial pronouncements on the Crown's obligation to consult with Aboriginal First Nations situated within British Columbia, adjudication of the Cheam's arguments in the context of the NEB is of significant importance to practitioners. ${ }^{19}$ What was of particular interest in this case was the fact that the NEB had undertaken significant public consultation efforts. Further, the issue of whether a sufficient Aboriginal title infringement existed so as to require overall project consent by an affected First Nation was indeed novel.

Another First Nations group, the Caribou Tribal Council, had also put Crown consultation obligations in issue, asking specifically whether a breach of the Crown's fiduciary duty had occurred in this case. These arguments had been raised by way of a preliminary Notice of Motion during GH-2-2002. However, before arguments were heard on the motion, it was withdrawn and the Caribou Tribal Council did not actively participate in the process. Given this conduct, one is left to speculate whether settlement was reached outside of the NEB's hearing room in satisfaction of the underlying concerns of the Project held by the Caribou Tribal Council. Mine Project, [2002] 4 W.W.R. 19 (B.C.C.A.); Haida Nation v. C.C. (Minister of Forests), [2002] 6 W.W.R. 243 (B.C.C.A.). For an excellent discussion of this topic, see also Thomas Isaac \& Anthony Knox, "The Crown's Duty to Consult Aboriginal People" (2003) 41 Alta. L. Rev. 49. Also, it is noleworthy to consider the NEB's policy on its distinct duties, as compared to those of the Crown, to consult Aboriginal people, as more particularly described in its Memorandum of Guidance. Consullation with Aboriginal People (4 March 2002) (NEB) [Memorandum of Guidance]. 
However, it would seem that the NEB found that the facts did not warrant a significant pronouncement on the requirements and scope of Aboriginal consultation. Instead, the NEB noted that Westcoast and the Cheam were negotiating an arrangement for the required reserve land rights, which were relatively limited in nature. ${ }^{20} \mathrm{~A}$ form of "consent" would be reached assuming that negotiations were successful; however, in the event that an arrangement could not be reached, Westcoast indicated that it would pursue construction of the required facilities on lands outside of the Cheam reserve.

This case demonstrates the extensive level of process that parties should expect from the NEB when public and Aboriginal concerns are perceived to be in issue. The regulatory costs of added process seem to be a small price for the perceptional benefits of the NEB taking a more inclusionary approach. Applicants face significant risks if they cannot demonstrate that meaningful consultation has occurred in advance of an application filing. Arguably, past practices used by pipeline companies, such as providing project information and identifying issues of public concern, may no longer be enough. Meaningful attempts to resolve such issues in advance of filing an application now seems to be the norm and, absent such steps, procedural delays should be anticipated.

Concerning the adequacy of the Crown's obligation to consult with Aboriginal peoples, the decision clearly indicates that this issue will be considered by the NEB. This is a key difference in practice, as compared to the AEUB or the Alberta Environmental Appeal Board (AEAB). ${ }^{21}$ However, what practitioners do not know yet from the NEB is what it believes to constitute adequate Crown consultation.

\section{b. Reasons for Decision in the Matter of Westcoast Energy Grizzly Expansion Pipeline and the Weejay Latera ${ }^{2}$}

On 31 January 2001, Westcoast applied for a certificate of public convenience and necessity pursuant to s. 52 of the $N E B A c t^{23}$ to construct and operate the Grizzly Extension Pipeline and the Weejay Lateral (the Project).

The Project would transport raw sour gas from the Ojay/Weejay and Narraway areas in British Columbia and Alberta to Westcoast's existing Raw Gas Transmission (RGT) system for delivery and treatment at the Pine River Gas Plant. The proposed $406 \mathrm{~mm}$ (sixteen inch) OD Grizzly Extension Pipeline would be approximately $109.5 \mathrm{~km}$ in length and would extend the Grizzly RGT system from the existing $508 \mathrm{~mm}$ (twenty inch) OD Grizzly Pipeline to a proposed producer receipt point in Alberta. The proposed $273 \mathrm{~mm}(10.75 \mathrm{inch})$ OD Weejay Lateral Pipeline would be approximately $5.0 \mathrm{~km}$ in length and would extend from the proposed Grizzly Extension Pipeline to a producer well in British Columbia. After convening a three day oral public hearing in June 2002, the NEB took five months to deliberate and issue GH-2-2002 in November, approving the Project.

The extent of the Aboriginal title infringement, in the author's vicw, in pant would be determined by the requirement for additional lands. All that Westcoast required in this case was land adjacent to its existing right-of-way which measured 20 meters in width by 190 meters in length.

See further discussion of AEUB Decision 2003-013 in infra nole 56, and the Alberta Environmental Appeal Board's decision Re: Chippewa Prairie First Nation, infra note 69.

(November 2002), GH-2-2002 (NEB).

Supra note 6. 
A preliminary issue arose over the manner in which the NEB proposed to carry out its statutory obligations under both the Canadian Environmental Assessment $\mathrm{Act}^{24}$ and its enabling legislation. As the project required more than $75 \mathrm{kms}$ of new pipeline right-of- way, it was made subject to the $C E A A$ comprehensive study reporting requirements (CSR).

The issue was whether the NEB was obligated under the CEAA to prepare a CSR before commencing its oral public hearing process, or whether the CSR could be prepared following the completion of the NEB's process. In finding that neither the CEAA nor the NEB Act required the CSR to be prepared in advance of the public hearing, the NEB took the opportunity to review and clarify the approach it uses to satisfy obligations arising under the $C E A A$ and its own enabling legislation for projects that trigger the CSR.

A few points are worth highlighting. First, the NEB has clearly indicated that there are two ways in which the CSR requirements under the CEAA may be fulfilled. Either the task may be delegated to the applicant so that a "draft" CSR report is prepared in advance of the NEB's oral public hearing process or, alternatively, the CSR is prepared in all respects by the NEB itself. The delegation option arises as a means to better coordinate the $C E A A$ and NEB requirements. In the past, there have been significant concerns expressed by industry over the incremental regulatory process, regulatory uncertainty and project delay created by the $C E A A$ 's CSR requirements. The concerns generally arise because the $C E A A$ requires the Minister of Environment to review the CSR, to convene a public consultation process into the CSR and to determine if an additional regulatory process is needed given, among other reasons, the level of public concern.

Delegating to the applicant the task of preparing a draft CSR has been intended to streamline the $C E A A$ and NEB process. The idea is that by preparing a draft CSR document in advance of the NEB's oral public hearing process it may be reviewed and commented upon in the subsequent NEB hearing process, thereby reducing uncertainty over the polential need for additional regulatory process.

However, a cautionary note appears to have been issued by the NEB to those who might think that delegation means a less rigorous regulatory process. As was the case here, if the draft CSR is not carried out to the NEB's satisfaction, then the NEB has the authority to withdraw the delegated responsibility; in doing so, potential regulatory efficiencies may be lost. In the case at hand, 16 months had passed between the time at which the application was first filed and when it was eventually set down for hearing. Presumably, it was within this time period that the applicant prepared its draft CSR. Given that the NEB subsequently withdrew the authority to prepare the CSR, an additional five months were taken by the NEB following the oral public hearing, presumably time taken to prepare an acceptable CSR. In hindsight, one cannot help but speculate whether less time overall would have been required if the CSR preparation task had not been delegated at all.

A second point of practice is that the evidentiary record in an NEB proceeding involving a CSR project will not "close" until such time as the Minister of Environment's review of the CSR and the public comment process under the $C E A A$ has been completed. This ensures that 
in the event that public concerns arise under the CEAA commentary process, the NEB may permit reconsideration of previously tested evidence without having to commence a new hearing process altogether.

While GH-2-2002 provides some insight into how the NEB carries out its obligations under the $C E A A$ and the $N E B A C l$, a statutory process that takes almost two years to complete and where no real or substantive environmental issues have been shown to exist is arguably a process in need of change.

Substantive improvements would arise, in the author's view, if amendments were made to the $C E A A$. One potential change would cause the NEB's process to be treated as a complete substitute for CEAA's CSR. While the Minister's review of the CSR, the public's need to be consulted on the CSR and a decision by the Minister on the need for additional procedural assessment steps are noble objectives, their application to projects that are subject to the NEB Act are arguably redundant. The NEB's existing process for CSR-type projects already require public hearings, environmental issues and assessments to be considered as part of the NEB's public interest requirements. Federal cabinet approvals are also required and presumably take into consideration the views or concerns of the Minister of Environment. What more, one must ask, is necessary or indeed within the public interest? ? $^{25}$

\section{c. Reasons for Decision in the Matter of Maritimes \& Northwest \\ Pipeline Management Ltd. Section 58 Application dated 6 March $2002^{26}$}

GH-3-2002 concerned an application filed by Maritimes and Northeast Pipeline Management Ltd. (M\&NP) on 6 March 2002 for the proposed compression expansion of the Maritime and Northeast Pipeline system. The new facilities would allow up to 422, $000 \mathrm{GJ} / \mathrm{d}$ of additional capacity for incremental gas supply to be transported from EnCana Corporation's (EnCana) Deep Panuke Field contemplated to commence production in 2005.

EnCana's gas supply would be produced and processed on platforms located in offshore natural gas fields near Sable Island. EnCana had planned to bring its gas onshore through a new subsea pipeline which would connect with the existing M\&NP mainline facilities near Goldboro, Nova Scotia. On 1 March 2002, EnCana filed applications for its Deep Panuke Project (inclusive of the new subsea pipeline) with the NEB and the Canada-Nova Scotia Offshore Petroleum Board (CNSOBP).

The main issue in this case related to the limited supply and conditional commercial support provided by EnCana to M\&NP for the requisite incremental pipeline capacity provided by the applied-for facilities.

Specifically, EnCana signed conditional firm service agreements with M\&NP for transportation on both Canadian and U.S. portions of the pipeline. While the agreements ensured that EnCana could transport or, in any event, would have to pay for transportation

2s However, the author notes that the idea of having the NEB's legislative requirements and process treated as a complete substitute to that arising under the $C E A A$ was proposed and rejected during the $C E A A$ five-year legislative review process. 
of up to $422,000 \mathrm{GJ} / \mathrm{d}(400,000 \mathrm{MMBtu} / \mathrm{d})$ of natural gas, the primary term of the transportation agreement was only ten years. This meant that since the new facilities would be depreciated over a much longer period, remaining shippers would be "at risk" for any undepreciated costs. Also, the agreements allowed EnCana the one-time right to decrease its initial maximum daily transportation quantity by an amount not to exceed $211,000 \mathrm{GJ} / \mathrm{d}$ by no later than 31 July 2003 . Since the applied-for facilities were designed to meet an incremental transportation capacity commitment of $422,000 \mathrm{GJ} / \mathrm{d}$ on both Canadian and U.S. portions of the M\&NP system, EnCana's potential exercise of its step-down option directly impacted the need and appropriate design of the new facilities. Interested parties to the proceeding had interests in the local Maritime market, with the government of New Brunswick in particular raising concerns over the timing of the application and the impact of EnCana exercising its step-down rights. Specifically, given the uncertain incremental supply situation, domestic interveners were concerned that they would not have an opportunity to contract with EnCana for Deep Panuke gas.

The facts in this case presented the NEB with a dilemma. Traditionally, the question of a project's economic feasibility is assessed through consideration of whether the applied-for facilities will be used at a reasonable level over their economic life and that the associated demand charges will be paid. In this regard, the NEB evaluates a number of factors, including: project-specific and overall gas supply; transportation arrangements; markets; potential competition; and the effects of any toll increases caused by the expansion. In this case, the only project-specific supply put forward was EnCana's Deep Panuke field. Supply from this field was projected to decline after just a few years and by year ten, the field would produce less than 20 percent of the volume contracted on M\&NP. As a result, the NEB found that the Deep Panuke field, by itself, did not provide a strong indication that the facilities would be used at a reasonable level. To overcome this deficiency, the NEB looked to evidence of the "prospectivity of the basin."27 Instead of relying upon expert supply forecasts, the NEB relied on the expected exploration work commitments in the basin by producers, including EnCana. As well, the NEB relied upon the positive net present value of the proposed expansion via EnCana's take or pay commitments and the immediate toll reductions that would accrue to all shippers by the expansion proceeding and with the $422,000 \mathrm{GJ} / \mathrm{d}$ of incremental contracted throughput.

While the NEB was somewhat liberal in its consideration of the economic feasibility issue, it remained concerned with the effect of EnCana potentially exercising its step-down rights. In the NEB's view, such an outcome would change the need for and economic feasibility of the applied-for facilities and would likely prompt a change in their design. As a result, the NEB granted a conditional approval such that its order would have effect at the latest on 31 July 2003, which was the deadline for the step-down option; or that M\&NP would have to make certain filings, one of them being the filing for approval of a revised engineering/hydraulic design in relation to the facilities proposed to support the contracted volumes if those were less than the originally applied-for level of $422,000 \mathrm{GJ} / \mathrm{d}$.

The NEB's acceptance of industry commitments to develop a nascent supply region as a surrogate for its more traditional supply evidence requirements and as justification for new 
facilities was novel. In hindsight, one must now consider whether this approach would be so readily accepted. The unfortunate fact is that there has been a continuing lack of drilling success in the Nova Scotia offshore area and, indeed, the Deep Panuke Project has now been delayed altogether. Whether these results would cause the NEB to revisit this approach is at least debatable.

\section{Miscellaneous Decisions}

a. Reasons for Decision In the Matter of Province of New Brunswick Application Respecting Short-term Export Order Procedures ${ }^{28}$

On 28 February 2002 the government of New Brunswick (New Brunswick) made application to the NEB requesting that new rules be established by it to govern the exportation of incremental natural gas supplies produced from the Nova Scotia offshore area.

Pursuant to Part VI of the NEB ACt, ${ }^{29}$ the NEB regulates the exportation and importation of oil and natural gas into and out of Canada. The NEB may issue licenses where approvals are required for terms in excess of two years. Orders may be issued for terms less than two years. In the past, it was common for the NEB to convene formal proceedings to consider export license applications. License requirements cause applicants to satisfy both the $N E B$ $A c t$, as well as the $C E A A{ }^{30}$ and tend to be lengthy processes. Alternatively, orders are processed by way of a short form of application and approvals have been issued by the NEB without substantive review and in as little time as one to five business days. In recent times, the utility of satisfying the more onerous license requirements process has been placed in doubt, given the notable reduction in such applications. Instead, the propensity has been for gas to be exported under orders, which orders may be re-issued with very little effort.

While export orders have been an efficient way for applicants to satisfy the NEB's regulatory requirements, they have been used while there has been no serious doubt raised about the capability of Canada's supply basins. With the continued lack of drilling success in the Nova Scotia offshore and the alleged inability of domestic gas buyers in obtaining supply to meet domestic requirements, the question raised by New Brunswick was whether the NEB's existing rules remain relevant and in the public interest for incremental reserves situated in the offshore area.

There is a long history to this issue. Briefly, New Brunswick has promoted the expansion of natural gas consumption in its province. In 2001, New Brunswick supported the development of the Cartier Pipeline Project. The intent was to see a new gas pipeline constructed between the existing Maritimes \& Northeast Pipeline Management Ltd. (M\&NP) system near Fredericton, New Brunswick and the TransQuebec and Maritimes Pipeline near Quebec City.

In 2001, PanCanadian Petroleum (PanCanadian, now EnCana) had announced plans to develop its Deep Panuke offshore natural gas field, and in so doing, was considering all 
potential transportation options, including potential service offered by Cartier and service provided by M\&NP. In late 2001 , PanCanadian announced its decision to support the expansion of M\&NP, thereby favouring the export markets served by this system over the domestic markets that might potentially be served by Cartier (New Brunswick, Quebec and Ontario). PanCanadian's business decision, coupled with the lack of any other proven sources of incremental supply, caused the Cartier proponents to announce an indefinite delay in their project plans.

While the business decision had been made, the only faint hope for New Brunswick to have gas access new regions of the province was to put in issue whether PanCanadian's supply had been offered to domestic purchasers on terms and conditions similar to those offered stateside. New Brunswick proposed to do this by having the NEB's export order rules changed for Nova Scotia offshore gas, so that on a go-forward basis the developing nature of the natural gas marketplace in the Maritime region was given due consideration in particular, given the incremental supply constraints.

Not surprisingly, the application was hotly contested by producer interests, who argued that the effect of New Brunswick's application would be to create new uncertainties for those parties who have invested or are planning to invest in the region. Instead of promoting development at a time where successes have been few, the effect of the application would be the opposite. Moreover, the application would abrogate the NEB's long-standing principles of deregulation and allowing the marketplace to operate with minimal regulatory oversight.

While the NEB accepted many of the concerns raised regarding the inability of the Maritime marketplace to develop and compete for incremental Nova Scotia offshore gas as against buyers in more mature export markets, absent demonstrable evidence of market dysfunction the NEB was not prepared to deviate from its long-established, market-based principles. New Brunswick had not proffered any direct evidence that Maritime gas buyers did not have access to Nova Scotia offshore gas supplies on terms and conditions similar to those in export markets or that any gas seller, such as PanCanadian, had refused to negotiate in good faith. As a result, the NEB found it to be inappropriate at this time to implement procedures that would unduly interfere with the normal operation of the market. Instead, the NEB decided to monitor the Maritime gas market formally and to issue public reports on its status. Also, it agreed to collect data on domestic and export prices through surveys and to publish the results in aggregated formats in order to improve pricing transparency. Such steps, however, pale in comparison to the relief requested by New Brunswick.

\section{B. ALBERTA ENERGY AND UTILITIES BOARD}

1. ULTIMA VENTURES APPLICATION FOR A SWEET MULTIWELL OIL BATTERY FERRYBANK FIELD ${ }^{31}$

On 26 February 200I, Ultima Ventures (Ultima) made application to the Alberta Energy 
and Utilities Board (AEUB) pursuant to s. 7.001 of the Oil and Gas Conservation Regulations $^{32}$ to obtain a licence for a sweet multiwell oil battery.

The main issue in this case was an objection filed from an adjacent landowner concerning traffic, noise, safety, road deterioration and communications. Several attempts had been undertaken by Ultima to meet with the landowner and to resolve the landowner's concerns. However, the landowner refused to participate in any meetings or negotiations with Ultima. The potential impact of one party refusing to participate in consultation and dispute resolution on the project regulatory approval process is a lesson to take from this case. While the AEUB has long encouraged parties to resolve differences through consultation and negotiation, when this is not possible, it begs the question of what process or steps can be taken to expedite consideration of the matter. In this case, over one year passed from the time that the application was filed to the time at which an examination panel heard the matter and another two months passed before a decision was issued. In the author's view, this case should be of some concern to practitioners and especially to clients desiring to minimize regulatory delay and uncertainty. It is perhaps time for "fast tracking" hearing procedures to be developed in circumstances where parties have, by their conduct, agreed not to participate in dispute resolution by means other than adjudication. To do otherwise arguably leads to significant delay.

\section{COMPTON PETROLEUM APPLICATIONS FOR A SOUR GAS WELL, BATTERIES AND ASSOCIATED PIPELINES, VULCAN FIELD ${ }^{33}$}

During the months of April through June 2000, Compton Petroleum (Compton) applied for a number of sour gas well facilities situated in the Vulcan area. Several landowners raised concerns to the AEUB about the applications. The AEUB became aware of increased development in the Vulcan field by a number of other operators, and the AEUB directed its staff to work with area operators and landowners to develop a coordinated approach for future oil and gas development in the area. A multi-stakeholder process was developed and Compton agreed to withdraw its applications on 22 August 2000 to work with the multistakeholder process and to determine how to proceed with future development in the area. However, Compton only participated in one formal multi-stakeholder meeting. As unresolved issues remained with some but not all of the stakeholders, Compton re-filed its applications and a public hearing was convened on 22 January 2002. Decision 2002-41 was then issued on 16 April 2002.

Given the nature of the applications, a central issue in this case related to the lack of effort undertaken by Compton to resolve issues of concern to the general public. Public consultation is no longer being treated as a "soft" issue by the AEUB. The decision demonstrates a clear expectation from the AEUB that applicants will participate in appropriate dispute resolution processes. Such processes have become an integrated component of the AEUB's regulatory process. While the substantive issues raised by interveners were found to have been adequately addressed by the applicant, the AEUB was nonetheless "concerned" with the consultation approach undertaken by Compton. In a 
strongly-worded decision, the AEUB outlined its expectations of parties and, in particular, of Compton:

In the [AEUB's] view, Compton failed to recognize that a key element to building and sustaining constructive community and stakeholder relations is providing information, listening to concerns, and then trying to resolve those concerns in a respectful and meaningful manner. In addition, as resource owners, Albertans need to be aware of Alberta's supply of energy and mineral resources and the importance of these resources to Alberta's economy and society. The [AEUB] believes the positional stances taken by Compton and the intervenors limiled the dialogue needed to explore solutions to resolve issues. lior appropriate communication to occur, all parties need to be willing to participate in meaningful dialogue. Additionally, the (AEUB] believes that the approach Compton took, logether with the perception of the area residents that Compton used a "divide and conquer attitude," led to the polarization. The [AEUB] believes proponents need to be aware of the potential for such perceptions and be sympathetic in attempting to understand these concerns. The [AEUB] believes that in order to be successful, Compton must demonstrate its corporate commitment to deal with issues and concems of the community it operates in.

With this in mind, the [AEUB] is concerned about Compton's lack of participation in the multistakeholder group. The [AEUB] notes that Compton attended only one meeting. The [AEUB] is of the view that when a representative of a company attends a multistakeholder group meeting, it is in its best interest to take an active role in the meeting, meet with the public, and establish dialogue. Of additional concem to the [AEUB] is that Compton did not attend subsequent meetings. However, the [AEUB] notes that Compton indicated that it intends to participate in future multistakeholder group meetings. The [AEUB] believes that this commitment will go a long way to provide the necessary steps to bring all of the parties together to establish the relationship necessary for an operator to operate as a good neighbour in a community. The [AEUB] expects Compton to adhere to its commitment. ?t $^{\text {th }}$

\section{PENN WEST PETROLEUM LTD. APPLICATIONS FOR PIPELINES AND MODIFICATIONS TO A BATTERY PEMBINA FIELD 35}

On 23 July 2001, Penn West Petroleum Ltd. (Penn West) applied to the AEUB for several pipelines to transport oil well effluent, salt water and fresh water to and from various wells and an existing battery facility in the Pembina area. An adjacent landowner filed concerns that remained unresolved, although attempts at resolution had been made by the parties. $A$ hearing into the application was convened on 13 March 2002 and the AEUB's decision was issued on 10 May 2002.

One of the main issues raised by the adjacent landowner was the impact of the directions outlined in AEUB Guide 30: Guidelines for Safe Construction Near Pipelines ${ }^{36}$ on ranching operations. Under the Pipeline $\mathrm{Acr}^{37}$ and its Regulation, ${ }^{38}$ all stakeholders who wish to conduct excavation activities of greater than $30 \mathrm{~cm}$ depth within an area 30 metres from either side of the edge of a pipeline must first notify and obtain approval from the pipeline owner. Notification provided by the stakeholder must be provided two full working days 
from the intended excavation date to allow the pipeline company to mark its lines so as to prevent harm or injury. ${ }^{39}$ The landowner in this case alleged that the notification requirements caused significant inconvenience and delay of necessary repairs to fences adjacent to existing pipeline facilities, potentially putting at risk livestock remaining at large. Both Penn West and the AEUB recognized the concerns of the landowner and admitted that industry-wide reexamination of the Guide and Pipeline Regulation perhaps was required. While the AEUB found that the notification requirements remained prudent and, in essence, that the public safety objectives outweighed those of landowner inconvenience, the AEUB suggested that Penn West permanently mark its pipeline facilities near fence lines.

While as innocuous as this case may seem, an interesting and potentially significant legal issue remains. Landowners affected by pipeline operations have not typically been compensated for the loss of rights or inconveniences sustained for restrictions placed upon their use and enjoyment of the $\mathbf{3 0}$ metre control area. Rather, compensation has historically been restricted to those rights related to the right-of-way itself.

Control zone compensation, however, has become very topical of late, particularly in cases involving the NEB. Under s. 112 of the NEB Act, a similar 30 metre control zone is established for federally-regulated pipelines. ${ }^{40}$ In the past, landowner claims for compensation in respect of these lands has been found by the Minister of Natural Resources to be a matter that could not be referred to a compensation arbitration panel under the $N E B$ $A c t$. Without such referral, landowners could not avail themselves of a more cost-effective statutory arbitration process in order to have control zone compensation issues resolved." Instead, such matters could only proceed by way of civil claim. This has in fact been the course of action taken by some landowners in Ontario, where a class action claim has been initiated against Enbridge and TransCanada. ${ }^{42}$

Recently, the arbitrable nature of control zone compensation was reconsidered by the Federal Court of Appeal. ${ }^{43}$ This decision suggests claims for such compensation as against NEB-regulated pipeline companies indeed may be legitimate and that arbitration proceedings under the NEB Act would be appropriate to determine if in fact rights have been interfered with and, if so, the level of damages arising from such interference. What is not yet clear is what impact, if any, this decision will have on provincially-regulated pipelines and their

.4 See definition of "controlled area" as found in s. 1(1) of the Pipeline ACt, supra note 37 and the interpretation and use of this term in s. 1(3) and s. 21 of the Pipeline Regulation, ibid. for ground disturbances.

Supra note 6. The NEB control zone is measured 30 metres from the edge of the pipeline right-of-way as opposed to the edge of a physical pipeline, as is the case under the Pipeline Regulation.

Arbitration proceedings under the $N E B$ Act obligate the pipeline company to pay for all legal, appraisal and other costs determined by the arbitration committec to have been reasonably incurred, provided that the awarded compensation exceeds 85 percent of the amount of compensation offered by the company. Where awards are less than the 85 percent threshold, the arbitration committec relains the discretion to make awards of costs which, if made, are to be paid by the pipeline company. See NEB Act, supro note 6 at s. 99.

: Specifically, a Statement of Claim filed with the Ontario Superior Court of Justice (Court File No. CP. 34306) names the Canadian Alliance of Pipeline Landowners' Associations, 488796 Ontario Ltd. and Ronald Kerr as plaintiffs and Enbridge Pipelines and TransCanada Pipelines Led. as defendants. The action was commenced under the Ontario Class Proceedings ACt, 1992, S.O. 1992, c. 6. 
landowners. Given the similarity of the purposes, objectives and statutory enactment of the control zone concept, one would think it likely for the issue of control zone compensation entitlement to migrate from the federal to the provincial sphere.

\section{NOVA GAS TRANSMISSION LTD. APPLICATION TO CONSTRUCT FORT SASKATCHEWAN EITENSION AND SCOTFORD, JOSEPHBURG, AND ASTOTIN SALES METER STATIONS ${ }^{44}$}

On 4 October 2001, Nova Gas Transmission Ltd. (NGTL) applied for authority to construct and operate $77.5 \mathrm{~km}$ of NPS 20 pipeline (Fort Saskatchewan extension) and to construct and operate sales meter stations to provide service to Dow Chemicals Canada (Dow) and Sherritt International (Sherritt).

This decision illustrates the AEUB's current approach to proposals to construct competitive natural gas transportation alternatives within Alberta. The AEUB acknowledged that a number of generic issues needed to be resolved to ensure fair and equitable competition for all natural gas pipelines in the province. Pending the resolution of those issues, it would review this application having regard to the issues of need, proliferation, cost accountability, least cost alternative and other questions related to the economic, orderly and efficient development of pipeline facilities in the public interest.

On the question of need for the proposed facilities, the AEUB examined whether the size of the market supported NGTL's proposed facilities and, secondly, whether or not there were other compelling reasons supporting the facilities. The AEUB concluded that, from a market perspective, NGTL's facilities were not needed at this time, principally because the majority of the proposed capacity was underpinned by volumes currently moving on the existing facilities of ATCO Gas and Pipelines LId. (ATCO). The AEUB examined security of supply and issues related to customer choice, noting that Dow and Sherritt did not approach ATCO with any concerns regarding security of supply, nor were any alternatives other than the NGTL proposal considered. The AEUB concluded that it would be unreasonable for ratebased regulated entities to build duplicate facilities in order to enhance the desired security of supply levels of certain select customers, as this would be unfair to remaining customers and would not promote cost efficiencies, to the detriment of all shippers. The AEUB concluded that the Fort Saskatchewan extension would not ensure cost efficiency, nor would it minimize adverse effects on other interested parties, but would violate the AEUB's policy on proliferation of facilities.

On the issue of the size of the proposed pipeline, the AEUB found that certain potential markets identified by NGTL were speculative and could not be used to underpin the proposed facilities. Accordingly, the proposed Fort Saskatchewan extension was oversized.

NGTL argued that its proposed facilities represented an overall less costly and more efficient method to serve the market. Conversely, ATCO argued that a TBO arrangement utilizing its existing facilities would provide material cost savings. The AEUB relied on 
evidence that indicated that the annual costs of various TBO options were about half the annual cost of service that would result if NGTL built the proposed facilities; the AEUB concluded that the NGTL option was not the least costly alternative.

Finally, the AEUB found favour with the evidence led by ATCO customers that the proposed facilities could lead to an increase in rates without any offselting benefits. While the AEUB acknowledged NGTL's assertion that increasing deliveries into the Fort Saskatchewan area would result in increased NGTL receipt revenue and lower tolls for all shippers, the AEUB noted that no evidence was presented to suggest that such incremental receipt volumes could not have accessed the NGTL system without the proposed facilities. Overall, the AEUB concluded that the potential rate increases arising from the construction of unnecessary facilities would not be in the interests of customers and shippers on either the NGTL or ATCO systems.

\section{ATCO GAS AND PIPELINES LTD. TRINSFER OF REGULATED CARBON STORAGE FACILITIES TO AN UNREGULATED AFFILIATE COMIANY, ATCO MIDSTREAM LTD."}

On 18 July 2001, ATCO Gas and Pipelines Ltd. (ATCO) applied to the AEUB for approval of a process whereby its Carbon storage facilities and related producing properties (Carbon Facilities) could be transferred to ATCO Midstream Ltd. (Midstream), an unregulated affiliate company. The Carbon facilities were included in the rate base of ATCO - South for rate-making purposes. ATCO had owned the Carbon facilities since 1957, using them as storage to meet the peaking requirements of both current customers and other storage customers, such as TransCanada PipeLines.

The AEUB first determined that there was evidence supporting the proposition that the Carbon facilities continued to be used and useful regulated assets, notwithstanding available alternatives and, accordingly, that the continued operation of such facilities remained appropriate. The AEUB indicated some uncertainty as to the Carbon facilities degree of usefulness and indicated that it would be willing to consider a sale of the assets on certain conditions, principally keeping customers harmless by establishing a "no-harm" value.

As to the fair market value of the Carbon facilities, the AEUB indicated that a more transparent public tender process including not only ATCO facilities, but any interested party, should be followed.

Finally, the AEUB concluded that the sale of regulated assets to a third party or their transfer to an affiliate should be made at fair market value. That said, the AEUB concluded that customers should not be harmed by the sale or transfer of such regulated assets and, accordingly, that the price should be such that customers would be no worse off than they would be if the asset or assets were retained by the regulated utility. This "no-harm" threshold, in the AEUB's view, should be determined in conjunction with a request for approval of a sale based on a firm price from a willing buyer. 
6. NOVA GAS TRANSMISSION LTD. GAS TRANSPORTATION TARIFF

CARBON DIOXIDE ( $\mathrm{CO}_{2}$ ) GAS QUALITY REQUIREMENTS PHASE $/ / \mathrm{CO}_{2}$

MANAGEMENT SERVICE AND TARIFF AMENDMENTS ${ }^{46}$

In 2002-44, the AEUB clarified the legal interpretation of the gas quality specification provisions set out in the tariff of Nova Gas Transmission Ltd. (NGTL). The decision resulted from a complaint by a number of petrochemical and related entities who asked the AEUB to require NGTL to comply with and enforce its $\mathrm{CO}_{2}$ specification at all receipt points. Having regard to the NGTL tariff, the AEUB found that NGTL had the discretion to accept onto its system natural gas containing more than 2 percent $\mathrm{CO}_{2}$ by volume, but also determined to convene a further proceeding to consider the appropriateness of the NGTL tariff specifications. Subsequent to the foregoing decision, NGTL and interested parties engaged in discussions and negotiations concerning a proposed $\mathrm{CO}_{2}$ management service. A proposal acceptable to interested parties was concluded and put before the AEUB for approval.

The essential terms and conditions of the proposed service, approved by the AEUB, were as follows:

- Shippers of gas with $\mathrm{CO}_{2}$ in excess of the 2 percent specification must arrange to process their gas to meet the specification themselves or, in the alternative, to subscribe to NGTL's $\mathrm{CO}_{2}$ management service to avoid being shut in;

- NGTL's proposed rates for the service were based on proxy pricing for typical aiming extraction plant costs on a tiered basis;

A tiered rate structure depending on volumes: at receipt points delivering less than $25 \mathrm{mmcf} / \mathrm{d}$ of natural gas the rates would be $\$ 15 / \mathrm{mcf}$ of $\mathrm{CO}_{2}$ removed; for points between 25 and $50 \mathrm{mmcf} / \mathrm{d}$ the rate would be $\$ 12 / \mathrm{mcf}$ of $\mathrm{CO}_{2}$ removed; and for points greater than $50 \mathrm{mmcf} / \mathrm{d}$ the rate would be $\$ 8 / \mathrm{mcf}$ of $\mathrm{CO}_{2}$ removed;

- NGTL will contract for $\mathrm{CO}_{2}$ removal and assess the contracted costs associated with foregoing rates; if the actual cost exceeds the tier price, NGTL's customer can select service at a higher priced tier or elect to pay a surcharge if the higher price tier does not cover actual costs;

Any excess revenue earned by NGTL will be shared with its customers, with NGTL receiving 10 percent of the excess revenue up to a maximum of $\$ 500,000$ per year as an incentive; and

$\mathrm{CO}_{2}$ "Receipt Zones" may be established by NGTL for deliveries to connecting pipelines that would experience deliveries of more than 2 percent $\mathrm{CO}_{2}$, in which case NGTL will contract for removal of excess $\mathrm{CO}_{2}$ or will make alternate arrangements with the connecting pipeline.

The proposed management service was premised on a March 2002 level of "Excess $\mathrm{CO}_{2}$ " of $16.1 \mathrm{mmcf} / \mathrm{d}$. NGTL will establish a "Service Cap" to limit the total amount of Excess $\mathrm{CO}_{2}$ by contracting for removal to achieve the 1999 level of Excess $\mathrm{CO}_{2}$ of $5.5 \mathrm{mmcf} / \mathrm{d}$. After five years the Service Cap will reduce to $4.5 \mathrm{mmcf} / \mathrm{d}$. 


\section{TRUENORTH ENERGY APPLICATION TO CONSTRUCT AND OPERATE AN OIL SANDS MINE AND COGENERATION PLANT IN THE FORT MCMURRAY AREA ${ }^{47}$}

This decision concerned applications made by TrueNorth Energy (TrueNorth) for approval to construct and operate its proposed $\$ 3.5$ billion open pit truck and shovel oil sands mine and bitumen extraction facility known as the Fort Hills Oil Sands Project (FHOSP). Approval was also sought for the construction and operation of a co-generation facility to be located at the mine site situated approximately $90 \mathrm{kms}$ north of Fort McMurray.

In terms of project dollar value, this was one of the most significant applications heard by the AEUB in the recent past. The decision approving the project could be the topic of a separate paper altogether, especially with respect to the many environmental, socio-economic and public consultation issues that consumed much of the regulatory proceedings and reasons issued by the AEUB.

One area worthy of discussion concerns the AEUB's consideration of resource conservation issues. The first such issue concerned TrueNorth's request for the relaxation of the resource recovery requirements contained in AEUB Interim Directive 200 1-7: Operating Criteria: Resource Recovery Requirements for Oil Sands Mine and Processing Plant Sites. ${ }^{48}$ Under ID 2001-7, minimum bitumen extraction recovery requirements are specified. TrueNorth was seeking modifications to these requirements for a three-year period, as well as modifications to the minimum ore grade requirements for the initial 60 million tons of feed expected to be mined during the first year of operations. These changes would result in the loss of 900,000 bbls of bitumen production. TrueNorth relied on the fact that other oil sands operations had operated under different minimum standards or had been issued relief similar to that requested. The AEUB refused TrueNorth's request. In so doing, it found that the requirements set out in ID 2001-7 resulted in a single set of operating criteria requirements for resource recovery that superseded the operating criteria requirements set out in each of the earlier approvals. As a result, previous exemptions for extraction recovery were no longer valid.

While not rejecting outright the possibility of relaxations being issued in the future, the AEUB held that the operating criteria outlined in ID 2001-7 were developed in consultation with the oil sands industry over a number of years and "that if an applicant is not going to meet operating criteria requirements, it must submit a full technical and economic justification to support its assertion that the relaxation was warranted."49 As TrueNorth apparently had not met this evidentiary standard, the AEUB refused to grant the requested relaxations.

A second resource conservation issue pertained to the siting of the proposed tailings pond, which was proposed to take place over the top of significant mineable oil sands, thereby decisions/2002/2002-089.pd\& [2002-089]. 
sterilizing the extraction of this resource. Concerns had been raised over the increase in the potential environmental effects if the tailings pond location was changed. Notwithstanding the AEUB finding that a change in location would have unacceptable environmental effects, these effects were seemingly outweighed by the sterilization impacts. The AEUB directed TrueNorth to reconsider the size and adequacy of the tailings pond and to conduct additional analysis to quantify the costs and benefits of relocation so as to minimize resource sterilization.

A third resource conservation issue concerned water use and disposal. TrueNorth noted that high salinity basal aquifers existed under the ore body and required depressurization in order to safely conduct mining operations. TrueNorth requested the ability to extract and reinject the high salinity water into a fresh basal aquifer at a location outside the perimeter of the ore body. Other options had been considered by TrueNorth, including treatment and use, but were found to be economically prohibitive and to have the potential of placing the entire project at risk.

The problem with TrueNorth's proposal was that it breached the provisions of AEUB Guide 5I: Injection and Disposal Wells: Well Classifications, Completion, Logging, and Testing Requirements ${ }^{50}$ - in particular, prohibitions concerning disposal into usable aquifers. An exemption from these requirements was therefore sought. TrueNorth had not considered other re-injection alternatives, such as re-injection into deeper geological formations that complied with the provisions of Guide $5 /$. While commitments to carry out this analysis were made during the hearing, TrueNorth continued to seek the exemption.

In rejecting True North's request, the AEUB relied on its "pre-eminent criterion" when considering disposal applications and protecting usable water zones. In so doing it upheld the provisions of Guide 5/, specifically the prohibition of contaminating usable water aquifers. While not precluding the possibility of exemptions being made on a case-by-case basis, the AEUB again seems to have suggested that such applications have a high threshold to overcome, requiring significant evidence to show other disposal methods are neither technically nor economically viable.

Two other issues not pertaining to resource conservation are also worth highlighting.

The first concerned the jurisdiction of the AEUB to hear and decide applications that may impact cabinet-approved integrated resource plans. TrueNorth's proposed operations were to take place within the McClelland Lake Wetland Complex (MLWC). In 1996, the Fort McMurray-Athabasca Oil Sands Subregional Integrated Resource Plan (IRP) had been developed and approved by the provincial government. The IRP specifically included a prohibition against open pit mining in the MLWC. Given this restriction, TrueNorth had applied to the Alberta government for a relaxation of the guidelines. Based on TrueNorth's 14 June 2002 submissions, the Alberta government amended the IRP to remove the prohibition against surface mining in the MLWC. While significant environmental work had been undertaken to examine the impacts of the proposed operation within the MLWC, 
TrueNorth took the position that the government's decision to amend the IRP released the AEUB from its obligation to decide whether it was in the public interest to destroy a portion of the MLWC to recover the bitumen. Further, TrueNorth believed that that decision had been taken by the government and that the AEUB was bound to follow that policy direction. It believed that the only decision facing the AEUB with respect to the wetland was whether the mitigation proposed by TrueNorth was suitable.

The AEUB rejected this argument. While finding IRPs to be expressions of public policy that the AEUB must consider, this did not mean that the IRP could be treated as a substitute for the regulatory responsibilities that the AEUB must carry out under the Alberta Energy and Uilities Board Act. ${ }^{\text {'I }}$ Such an approach would be a fettering of the AEUB's authority. Instead, the AEUB found the IRP to be a guidance document only, without any legal status. Tuming to the issue at hand, the AEUB weighed the benefit of recovering the estimated one billion barrels of bitumen underlying the MLWC against the direct environmental impacts and concluded that, in the broader context, it was in the public interest to approve mining within the MLWC, subject to TrueNorth establishing and implementing an appropriate mitigation plan.

A final issue of interest arising in this decision was whether TrueNorth, as a limited partnership, was considered to be a suitable form of business organization to hold approvals. The concern centred around whether TrueNorth would remain responsible for decommissioning, reclamation and broad public/environmental liabilities that may arise during the construction and operation phases of a project.

The AEUB held that in the absence of compelling reasons to reject such arrangements, limited partnerships were acceptable entities to hold approvals. The existence of limited liability for limited partners, for example, of itself was not found to be sufficient reason to deny approval for an applicant's project. The AEUB went on to find that:

However, the government and public are entilled to have successful proponents provide a financial mechanism for the funding of broad public/environmental liability for contingencies that may arise during construction and operation of an oil sands mining project, as well as for the reclamation and decommissioning of the site and plant at the end of the project's life. This is especially important where applicants have limiled assets at the time of the application for approval and the financial strength of the final ownership structure is unknown. The [AEUB] acknowledges that Alberta Environment will require a deposil or posting of security with respect to the reclamation liability of TrueNorth under the provincial environmental legislation. Depending on the specific circumstances before the [AEUB], proponents may also be required to post performance bonds, makc security deposits, establish internal or external accounts in which funds from revenue are deposited on an ongoing basis for reclamation, abandonment, and decommissioning, and obtain both third-party and environmental damage insurance coverage. In some cases, the [AEUB] may ask for security instruments to also be provided by an applicant's corporate parent or affiliatc. The [AEUB] directs TrueNorth to prepare a report for submission to the [AEUB] that addresses the manner in which TrueNorth will provide not only for the accounting but for the funding of the liabilities outlined above. This report is due on the expiry of 12 months after the start of construction. With respect to the appropriate insurance requirements, the applicant must obtain an insurance review by an independent consultant to determine the appropriate level of 
environmental and third-party liability coverage and submit it to the [AEUB] prior to the commencement of construction. 32

This passage highlights the AEUB's new expectations, which limited partnership applicants should anticipate facing when applying for regulatory approvals. While the requirements themselves appear to be dependent upon the nature of the application, they should nonetheless be of some interest to practitioners whose clients intend to seek regulatory approvals for projects that potentially have significant abandonment or reclamation issues.

\section{BUSHMILLS ENERGY COMPULSORY POOLING MEDICINE LODGE AREA, SECTION 6-53-2IW5M 33}

This decision involved an application by Bushmills Energy (Bushmills) for a compulsory pooling order in respect of all gas within the Viking Formation underlying a drilling spacing unit (DSU). The DSU was in respect of one section of land; Bushmills and its partners had obtained all rights to produce gas within the west half of the section. No producing wells were situated within the section; however, Bushmills was intending to drill a well within the west half of the section. Talisman Energy (Talisman) held rights to the east half of the section. Efforts to obtain a voluntary pooling agreement had been unsuccessful and, therefore, an application to the AEUB for a forced pooling order was made.

One of the central issues in this case concerned the allocation of costs and revenues under the proposed pooling order. Section $80(4)(c)$ of the Oil and Gas Conservation $\mathrm{Act}^{54}$ states that allocation of production under a pooling order "shall be on an area basis unless it can be shown to the AEUB that that basis is inequitable." Bushmills proposed that costs and revenues be shared on an area basis with a 50 percent allocation to each half of the section. It argued that, without any wells drilled in Section 6 to provide geological information, this allocation would be equitable under the pooling order.

Talisman submitted that if the AEUB decided to issue a pooling order, based on its geological interpretation, it would be inequitable to pool the interests in the section on an area basis as proposed by Bushmills. Talisman initially proposed a risk-based pooling method, with an allocation of 30 percent to Bushmills and 70 percent to Talisman, having regard for the three producing wells to the east and south of the section and an abandoned well to the west of the section. Subsequently, Talisman submitted that its more detailed geological mapping supponted a reserves-based allocation method of 13 percent for Bushmills and 87 percent for Talisman.

In their report, the examiners noted the fundamental problem that no wells in the section existed and that, therefore, no specific data was available. Further, Bushmills and Talisman had presented significantly different interpretations with respect to the potential reserves distribution within the section. Notwithstanding the lack of information on these points, the examiners in any event were able to find that an area basis allocation was inequitable.

(20 December 2002), AEUB Decision 2002-113 (AEUB), online: AEUB <unnw.eub.gov.ab.ca/bbs/ documents/decisions/2002/2002-113.pdP.

s.

R.S.A. 2000, c. 0-6 [OGCA]. 
They did so by considering the existence of offsetting well control and relied on the fact that reservoir sands were absent in an abandoned well situated only 350 metres from the western boundary of the section, which provided useful information to define the western limits of the pool. They determined that Bushmills, the applicant, had failed to provide sufficient evidence to demonstrate that equal reserves potential existed. Instead, the examiners held that an allocation on an area basis would not be equitable, when relying on the location of the abandoned well and the absence of reservoir sand, as well as the belief that reasonable contouring of the existing well data would show that more reserves existed on the east half of the section.

Given this finding, the examiners turned to the appropriate allocation method. The factors relied on by the examiners to reject an area basis allocation method - namely, available offset well control and well contouring - were also rejected in making a precise reserve allocation, as was the position of Talisman. The examiners held that where a party asserts a significant disproportionate reserves-based allocation, clear and convincing evidence is necessary in order for the examiners to recommend the allocation. In this case, the evidence presented did not meet this standard and, accordingly, Talisman's proposed 87/1 3 allocation was not justified. As a result, the examiners found that the views of the parties represented a range of extremes within which an appropriate and equitable allocation of reserves existed. Without providing any substantive reasoning in the report (other than the phrase "after weighing the evidence presented"), the examiners determined that an allocation of 60 percent to the east half and 40 percent to the west half was appropriate.

The decision provides insight into the evidentiary burden required to overcome the area basis allocation methodology as specified in s. $80(4)(\mathrm{c})$ of the OGCA. Two evidentiary thresholds exist. The first concerns the presumption in favour of area allocation which must be demonstrated to be inequitable. The second, and what seems to be the more challenging burden to overcome, is providing sufficient evidence to support a particular reserve-based allocation. What level of evidence is required is not known and appears to be fact-specific. However, the higher burden would also seem to allow the AEUB latitude to impose equitable compromises of its own making. In this case, recall Talisman's going-in position was a 70/30 allocation. Bushmills was $50 / 50$. The AEUB ultimately approved a $60 / 40$ result. How it derived this is not known, but the math would suggest that the difference in positions was simply divided. ${ }^{\text {s }}$

3s Readers interested in this decision may also wish to consider Petrobank Energy and Resources Lld. and West Slar Oil \& Gas Lid. Compulsory Pooling Morinville Ficld (3 Seplember 2002). AFUB Decision 2002-077 (AEUB). In thut case and based on log and drill stem test data presented from wells drilled within the DSU in question, the examiners also found a tract area basis allocation methodology attributed to the entire DSU to be inequitable. Further, the examiners rejected a reserve-based allocation methodology given the equally reasonable yet divergent interpretations of the reserves presented by the parties. Allocation of costs and revenues to each owner in the section was determined to be proportional to each owner's interest within the quarter section, within which the pool in question was proven to exist. 


\section{CANADIAN NATURAL RESOURCES LIMITED APPLICATIONS FOR NEWV AND AMENDED PRIMARY RECOVERY SCHEMES AND WELL LICENCES, LINDBERGH SECTOR, COLD LAKE OIL SANDS AREA ${ }^{\text {S6 }}$}

Canadian Natural Resources Ltd. (CNRL) applied to the AEUB pursuant to s. 10 of the $O G C A$ for approval to construct and operate a new scheme and to amend two existing schemes for the recovery of crude bitumen from the Mannville Group in the Cold Lake Oil Sands Area. Among other aspects, CNRL applied for drilling spacing units being added to the scheme be reduced in size from 64 to 80 hectares, and wells drilled or to be drilled within the area to have a minimum interwell distance of 100 metres and a project boundary buffer of 50 metres. CNRL also sought approval pursuant to s. 2.020 of the Oil and Gas Conservation Regulations for licences to drill three vertical wells for sweet gas production and 54 wells from 13 well pad sites for the purpose of obtaining crude bitumen production from the Mannville Group.

A number of parties had filed statements of concern in respect of the application. However, most concerns were addressed through appropriate dispute resolution prior to the AEUB's oral public hearing into the matter.

Outstanding concerns remained with two First Nations Groups. The Frog Lake First Nation (FLFN) and the Kechewin Cree Nation (KCN) alleged that the Crown had not fulfilled its constitutional fiduciary obligations to consult with the First Nations. This requirement, it was argued, entitles the First Nations to a process unique from that established by the AEUB. There were four essential points to their position. First, the lands upon which the applicant's development was proposed were traditional territory and traditional lands. Second, the applications would have a direct impact on FLFN's and KCN's treaty rights as Treaty First Nations with rights under Treaty $6 .^{37}$ Third, the treaty rights enjoyed by the FLFN and $\mathrm{KCN}$ are contained in s. 35(1) of the Constitution Act, 1982. ${ }^{38}$ Any infringement of their constitutionally-protected rights gave rise to a constitutional obligation on the part of the Crown and a corresponding constitutional right of the First Nations to be consulted on decisions that affect their Treaty rights. Fourth, this constitutional requirement imposes an obligation on the AEUB to ensure that before any decision is made, the FLFN/KCN's right to be consulted under s. 35 of the Constitution Act, 1982 must be fulfilled. ${ }^{39}$

The FLFN and KCN sought the following relief from the AEUB:

either exercise its own jurisdiction to engage in the constitutionally-required consultation with them; or

suspend any decision on the CNRL applications unless and until the Crown has fulfilled its requirement for constitutional consultation; and

in any case, should the CNRL applications be approved, impose conditions on

s. (1I February 2003), AEUB Decision 2003-013 (AEUB).

37 Supra note 55 at 5.

3* Constitution ACt, 1982, being Schedule B to the Canada Act, 1982 (U.K.), 1982. c. 11 |Constitution Act, 1982].

34 FLJN and KCN did not take issue with the consultation performed by the applicant. Instead, the consultation issue was restricted to the Crown's obligation arising under s. 35 of the Constitution Act, 1982, ibid. 
CNRL to ensure that appropriate mitigation and compensation measures, developed in consultation with FLFN and KCN, are met.

Without commenting on the alleged constitutional obligation to consult of the Crown in right of the Province, the AEUB refused the relief requested by the FLFN and $K C N$. In doing so, the AEUB relied on its quasi-judicial character, independent of government and possessing only those powers and duties set out in its governing legislation. The obligation to consult under the governing legislation applied only to applicants (as opposed to the Crown). The duty of the AEUB arising from this obligation is that if it appears that a decision may directly and adversely affect the rights of a person, the AEUB must give that person a reasonable opportunity to furnish evidence on how the application will affect her or him and to make representations to the AEUB. Once the process for hearing the application is established, the AEUB expects that all parties will participate in the proceedings so that each party is given an opportunity to hear, present and cross-examine evidence relating to the application.

The AEUB went on to note that, under the current legislation, there was no method or process permitted by law for the AEUB itself to engage in constitutional consultation as requested by the FLFN and KCN. As a quasi-judicial body, the AEUB held that it must remain independent from the parties appearing before it. Further, it found that CNRL had complied with all consultation requirements under the AEUB's legislation and specifically Guide $56^{60}$ and, therefore, held there were no grounds to suspend proceedings until further consultation with the FLFN and KCN by the AEUB or the Crown had taken place. Finally, insufficient evidence about the impacts of the applications on the FLFN and KCN prevented the AEUB from imposing conditions intended to mitigate them.

The legal obligations associated with "applicant consultation" and "Crown consultation" and the timing of each remain topical legal issues which are likely to receive more judicial consideration in the coming year. ${ }^{61}$ While both the NEB and the AEUB have taken a common view in finding it inappropriate for quasi-judicial tribunals (including, one assumes, their staff) to fulfil Crown consultation obligations, an important distinction remains. The NEB has indicated that it will not proceed to hear applications (that is, that the application may be considered deficient) which may affect First Nation interests, unless it is first satisfied that Crown consultation obligations have been met. ${ }^{62}$ Both Crown and applicant consultation obligations are highly relevant considerations in NEB proceedings. The prospect of regulatory delay is obviously good news for those seeking additional bargaining power to reach better accommodations with project proponents. Yet the difficulty with this approach is that it is ultimately the proponent who is placed at risk for the Crown to meet its consultative obligations in a timely manner.

In contrast, the AEUB's approach, at least as described in the present case, suggests that only applicant consultation obligations are relevant considerations in its proceedings. While 
applicant consultations with First Nations may be a component of this requirement, they are distinguished from any Crown consultation obligations arising with First Nations as a result of the Constitution Act, 1982. The AEUB's approach of segregating the Crown's constitutional consultation obligations, in the author's view, eliminates the potential regulatory delay otherwise arising at the outset of NEB proceedings. However, the AEUB's approach is not without some risk. Segregation of the Crown's obligation to consult still begs the question of whether this obligation will be a condition precedent to development proceeding or whether its outcome will have bearing on the AEUB's decisions concerning a project.

A choice between the lesser of two potentially unsatisfactory outcomes seems to arise for project proponents: on the one hand, a proponent could proceed with AEUB approvals and ignore any obligations that the Crown may have to consult, but in doing so it assumes the risk that Crown consultation will occur without impact upon the AEUB decisions or project timing. On the other hand, a proponent could attempt to have the Crown fulfil its consultation obligations before proceeding to the AEUB, which of course presumes that the Crown believes that it has an obligation to consult in the instant case and that such efforts will result in a timely and satisfactory outcome.

In the author's view, uncertainty surrounding the impact of applicant and Crown consultation obligations is not likely to be resolved without further guidance from the courts. In particular, what is needed is a better understanding of determining when Crown consultation must occur in the context of formal regulatory proceedings. In turn, appropriate government initiatives need to be undertaken to ensure that Crown consultation is achieved in an efficient and effective manner.

\section{Petrovera Resources LtD. APPLICATIONS For a PRIMARY RECOVERY SCHEME AND WELL LICENCES, LINDBERGH SECTOR, COLD LAKE OIL SANDS AREA ${ }^{63}$}

In a similar application to that made by CNRL in 2003-13, Petrovera Resources Ltd. (Petrovera) also sought approvals pursuant to s. 10 of the OGCA to construct and operate a primary scheme for the recovery of crude bitumen from the Mannville Group in the Cold Lake Oil Sands area. In this case, Petrovera also proposed that the drilling spacing units be reduced from a one well per section (64 hectares) to a quarter section (eight hectares) to increase recovery of bitumen. Petrovera maintained that reduced spacing would increase recovery to 7 percent, compared with 2.7 percent under quarter-section spacing.

As part of its planned development in the area, pursuant to s. 2.020 of the Oil and Gas Conservation Regulations, Petrovera applied for 13 additional well licences in order to drill vertical wells to obtain crude bitumen production from the Mannville Group formation. Also, the AEUB considered objections raised in respect of three wells that had received earlier approvals by way of routine applications. Petrovera agreed to suspend activity at these three wells pending review of the original applications at a formal proceeding. 
A local landowners group raised general concerns with the proliferation of wells within the scheme area. Two primary concerns were raised: the potential risks of contamination to local water supplies occurring and the level of gas venting proposed under the scheme.

With respect to the former, particular concern over one well was highlighted given its potential to impact the shallow water wells supplying the Hamlet of Lindbergh. The Lindbergh Group indicated that its concerns were related to surface activities at the proposed 2-3 well and to the drilling of wells through the aquifers, but not to the recovery of the crude bitumen reserves located under these lands. The Lindbergh Group's concerns were based on the belief that many of the wells also would be located in the recharge area of the shallow aquifer system it used as a water source.

Despite the low probability of an uncontrolled water supply contamination, and Petrovera's commitments to mitigate such potential effects, the AEUB found the consequences of such risk to be unacceptable given the potential significance and long-term impacts. It therefore refused to permit surface activity in the south half of Section 3.

Further, given the outstanding uncertainties respecting the extent of the recharge area for the aquifers, and the associated concerns raised by the Lindbergh Group, the AEUB directed Petrovera to take measures to define the recharge area of the aquifer system and provide this information to the Lindbergh Group and the AEUB prior to filing any applications for wells proposed to be located in the north half of Section 3.

With respect to the gas conservation and venting issue, Petrovera had made commitments not to vent more than $500 \mathrm{~m}^{3} / \mathrm{d}$ on any individual operating site. Petrovera stated that each well typically required about $300 \mathrm{~m}^{3} / \mathrm{d}$ of fuel gas to operate; hence, a four-well pad would have a fuel requirement of $1,200 \mathrm{~m}^{3} / \mathrm{d}$. Petrovera stated that conservation would be implemented in that case if pad volumes reached $1,700 \mathrm{~m}^{3} / \mathrm{d}$. This was based on a typical four-well pad that would use the first $1,200 \mathrm{~m}^{3} / \mathrm{d}$ as fuel and vent the remainder up to 500 $\mathrm{m}^{3} / \mathrm{d}$. If venting on such a site exceeded $500 \mathrm{~m}^{3} / \mathrm{d}$, conservation of the volumes in excess of site fuel requirements would be implemented or, if conservation were not economic, the excess gas would be flared.

Raising concerns over the cumulative impacts of development and, in particular, the lack of co-ordinated conservation schemes in the Elk Point/Lindbergh area, the Lindbergh Group sought further reductions to Petrovera's scheme. The Linbergh Group relied on Ranger Oil Limiled Cold Lake Oil Sands Area Primary Recovery Scheme, ${ }^{\text {at }}$ where the AEUB conditioned an order that required at least 75 percent conservation at sites where produced gas volumes exceeded $140 \mathrm{~m}^{3} / \mathrm{d}$. It argued that there was no reason that similar provisions should not apply to Petrovera's proposed project.

The AEUB found that the facts in the present case were distinguishable from those arising in 2000-23. In reviewing the requirements outlined in EUB Requirements for Evaluation of Solution Gas Vent Gas Conservation, ${ }^{65}$ the AEUB accepted Petrovera's commitment not to 
vent produced gas when vented volumes exceed $500 \mathrm{~m}^{3} / \mathrm{d}$ on any operating site. However, it also found that greater conservation of vented gas was possible and should be considered on a broader scale.

The AEUB found that significant gas volumes are vented in the Elk Point region of northeastern Alberta and that industry co-operation is necessary to improve conservation. It was not clear whether operators venting gas in an area are routinely collaborating to evaluate the potential for developing joint solution gas conservation schemes. The AEUB indicated that solution gas would be economical to conserve if competing licensees co-ordinated their efforts in an efficient, co-operative process that takes advantage of combined gas volumes and economies of scale.

As a result, the AEUB stated its expectation that all licensees in an area should exchange production data and jointly consider clustering of solution gas production and regional gas conservation systems. Further, the AEUB found that solution gas conservation economics will be enhanced if conservation is incorporated into the initial planning of larger multi-well projects.

With respect to Petrovera, the AEUB conditioned its approvals to require Petrovera to assess produced gas conservation within 90 days following initial production at each site and to reassess non-conserving sites not less than once per year thereafter. Also, and as part of the conservation evaluations, Petrovera was required to contact licensees formally of production facilities within a one kilometre radius of each of its non-conserving sites and to investigate joint options for conserving produced gas. Finally, the AEUB imposed a further condition requiring Petrovera to submit gas conservation evaluation audit packages for all sites where conservation will not be implemented. The evaluation package was required to include documentation indicating the actions taken by Petrovera to assess joint conservation opportunities with other operators in the area, including information on gas flaring and venting rates. The evaluation information for non-conserving sites was required to be submitted to the AEUB Operations Group at the end of the calendar quarter in which the evaluations were completed until all sites have been evaluated.

\section{BP CANADA ENERGY RATEABLE TAKE \\ BLACKSTONE BEAVERHILL LAKE A POOL}

BP Canada Energy Company (BP) applied to the AEUB under s. 36 of the $O G C A$ for a rateable take order distributing production from the Blackstone Beaverhill Lake A Pool among five wells. Canadian 88 Energy (Canadian 88), Husky Oil Operations Ltd. (Husky), and PCC Energy (PCC) filed submissions opposing the application, while Devon Canada (Devon) filed a submission in support of the application.

The issue in this case concerned allegations of inequitable drainage to the Blackstone Swan Hills Unit No. 1 reserves in the Blackstone Beaverhill Lake A Pool caused by production from an adjacent non-unit well (the 4-10 well) and the potential for further impacts attributed to an additional proposed non-unit well (the 1-9 well). BP, the unit 
operator and majority interest owner, indicated that unit wells were producing at their capacities and that if the application were denied, the unit would need up to 30 additional wells drilled to alleviate drainage fully, or as many wells as could be justified economically to reduce the amount of drainage. BP concluded that the addition of any new wells, pipelines or processing capacity to obtain accelerated production from the A pool would result in needless proliferation of facilities, have an unnecessary impact on the environment and not constitute economic, orderly and efficient development.

The drainage issue gave rise to arguments concerning how the common law rule of capture applied to the AEUB's statutory jurisdiction and authority. The AEUB acknowledged that the rule of capture is a fundamental principle of common law entitling the owner of valid oil and gas rights to any oil or gas that it produces through its well, regardless of whether the oil and gas produced originally underlay property owned by the producer. However, it held that the rateable take provisions of the OGCA authorize the AEUB to modify the rule of capture and to override the competitive operations that are the normal practice in Alberta. The AEUB went on to find that rateable take orders constitute a serious intervention in normal operations and that any application for such an order must be given very careful consideration. Before such orders may be granted, the applicant must demonstrate that it is being deprived of an opportunity to obtain its share of production from the pool. The relevant factors considered by the AEUB in this regard were reviewed in detail. In this case, the AEUB found that BP had not met the threshold. While accepting that drainage to the pool was likely to continue if a rateable take order was not issued, such an order could not be justified simply because one operator encountered a thicker or higher productivity zone or developed a more productive well. Further, and despite BP's past failure to reach agreements, the AEUB found that BP continued to have future opportunities to address the drainage issue through voluntary agreements and that such an outcome would provide the best long-term solution.

Turning to the issue of proliferation of facilities, the AEUB accepted that the existing wells in the unit were producing at their capacity and that, absent a rateable take order or a negotiated settlement, BP's only remaining option to address the drainage issue was to drill additional wells. In this regard, the AEUB considered two questions:

- whether it would be reasonable to expect BP to drill additional wells and whether such wells would constitute development that is not economic, orderly and efficient; and

- whether there were any facility constraints that would need to be addressed if additional wells were drilled and, if so, whether such constraints constitute an impractical and unreasonable option for BP.

In so doing, the AEUB relied on BP's statement that the unit would drill as many additional wells as could be justified economically to reduce the amount of drainage occurring. In the AEUB's view, only a few wells would be needed to alleviate a significant amount of drainage. Given the lack of environmental or other constraints, the drilling of new wells to maintain a competitive position in the pool was considered acceptable. 


\section{CHARD AREA AND LEISMER FIELD ATHABASCA OIL SANDS AREA} APPLICATIONS FOR THE PRODUCTION AND SHUT IN OF GAS

The issue before the AEUB was gas versus bitumen production and was significantly considered in 2003-23. As the issues involved in this decision are the topic of a separate research paper in this issue, ${ }^{68}$ it is only mentioned briefly here.

The AEUB's main conclusion was that where gas is associated with bitumen, gas zone depressurizing should be minimized more effectively to ensure successful bitumen operations in terms of recovery and of minimizing the technical difficulty of managing steam-assisted gravity drainage (SAGD) fluids. The AEUB further found that given the number of uncertainties about the technical and economic parameters surrounding SAGD bitumen recovery, its responsibility to ensure long-term recovery was not jeopardized by the production of gas in pressure communication with significant bitumen resources.

\section{EnVironmental. Appeal Board \\ 1. RE CHIPPEWA PRAIRIE FIRST NATION"}

This case also concerned the topic of the Crown's obligation to consult with First Nations and the impact that such consultation may have on regulatory approvals for natural resource developments in Alberta. Enbridge Pipelines (Athabasca) (Enbridge) had applied for and received approvals from the AEUB to construct certain facilities in the vicinity of Chippewa Prairie First Nation (CPFN) Treaty lands. Approval under the Environmental Protection and Enhancement $A C^{30}$ was issued to Enbridge for construction and reclamation of the new facilities. The CPFN appealed the approval and applied for a stay of the approval until an appeal was heard by the Environmental Appeal Board (EAB).

The EAB held that the CPFN's application for a stay was tantamount to an application for an interim injunction based upon an alleged breach of the right to be consulted. It found that, since the application was premised upon constitutional issues of the Crown's obligation to consult and not upon expertise in environmental issues, the matter was more properly suited for determination by a court of law. This would have the effect of allowing the Attorney General to be notified and provide the approval-holder the opportunity to present argument and oppose the application on the basis of common law injunction principles. Such relief was found to be broader in scope than the EAB's power to grant stays. As a result, the EAB granted the applicant time to make its application to court and advised that if it were successful, the $\mathrm{EAB}$ would immediately act on it by granting the stay request in a consistent manner. 
As the CPFN decided not to pursue this course of action, the courts were never provided with an opportunity to determine the outstanding issue." However, the case illustrates an important practice point concerning the reluctance of provincial expert regulatory tribunals to make determinations about the need or sufficiency of the Crown's constitutional obligations to consult. The clear message is that this is an issue to be addressed by courts, and for the issue to have any significant effect, it must be raised early in the regulatory process. What the effect might be upon provincial natural resource developments unfortunately remains uncertain at this time.

\section{IMPERIAL OIL \& LYNWOOD HOMES}

a. Imperial Oil Ltd. v. Alberla (Director, Enforcement \& Monitoring, Bow Region, Regional Services, Alberta Environment $)^{2}$

This case concemed the issuance of an environmental protection order (EPO) under what was then s. 102 of the $E P E A^{73}$ by the Director against Imperial Oil Lid. (Imperial Oil) in respect of releases of hydrocarbon affecting the Calgary community of Lynnview Ridge. ${ }^{74}$ The hydrocarbon and lead releases had occurred well before EPEA came into force. The EPO required Imperial Oil to undertake significant assessment and clean-up tasks due to the prior releases.

Two issues central to the appeal concerned the appropriate burden of proof and standard of review in matters before the EAB and whether s. 102 of the EPEA allowed the Director to issue EPOs having retrospective effects.

With respect to the first issue, the EAB confirmed that the standard of review concerning the Director's decision to issue an EPO was one of correctness and that the burden of proof rests with the appellant. The EAB held that it reviews Director's decisions under the correctness standard as warranted by the de novo nature of its review proceeding, its own expertise, its role in recommending the correct decision to the Minister, and the deferential view of the courts to its decisions.

With respect to the second issue, the EAB found that the Director had not applied s. 102 retrospectively by issuing the EPO. While the EPO had retrospective effects, the EAB found that its focus was largely upon the ongoing pollution and the mitigation of potential adverse effects. A distinction was drawn between a single event which occurred at a specific time and the release of substances over an indeterminate period that continue to migrate through the environment and present a continued threat of adverse effects. Thus the EAB was not prepared to conclude that the release in the present circumstances was a completed past event. $^{75}$ for not proceeding was that construction of the pipeline facilities had been completed, in essence making the point moot.

(2003), 47 C.E.L.R. (N.S.) 170 (EAB).

Supra note 70.

The EPO was issued to Imperial Oil and its wholly-owned subsidiary, Devon Estates Lid. 
With respect to the common law presumption against the retrospective interpretation of legislation, the EAB further held that this presumption had been rebutted both by the intent of the EPO to protect the public rather than punish the applicant and by the express wording and intention of the legislature for such orders to apply to ongoing pollution that originated before the EPEA came into force. In so doing, the EAB relied upon the Supreme Court of Canada decision in Brosseau v. Alberta (Securities Commission), ${ }^{76}$ in which the Court found that the presumption against retrospectivity was inapplicable to statutes that impose a penalty for a past event, "so long as the goal of the penalty is not to punish the person in question, but to protect the public."

\section{LEgisl.ATIVE DEVELOPMENTS}

\section{A. Federal and Territories}

\section{NATIONAL ENERGY BOARD COST RECOVERY REGULATIONS ${ }^{78}$}

In March 2001, amendments were made to the NEB's Cost Recovery Regulations, in part, to provide for a cost recovery cap on the liability of certain pipeline companies. The amendments provide that no pipeline company shall be liable to pay that portion of their cost recovery charge that exceeds 2 percent of the cost of service of that pipeline. This was intended to protect large diameter pipelines of short length from bearing an inequitable share of the NEB's costs, given that costs are allocated to large oil and gas pipelines on the basis of volumes transported through the pipeline.

Due to a drafting oversight, no provision was made in the amendments to reallocate any cost recovery shortfall that is created following the application of the cap to qualifying companies. The NEB was unable to recover this shortfall from other large pipeline companies and would not meet its cost recovery requirements.

In October 2002, further amendments were made to address this oversight. ${ }^{79}$ The new amendments provide for a redistribution of the shortfall for 2002 and subsequent years. Where a gas company qualifies for the cap, the shortfall will be redistributed amongst other large gas pipeline companies and the shortfall from oil companies subject to the cap will be redistributed to other large oil companies.

\section{NATIONAL ENERGY BOARD PROCESSING PLANT REGULATIONS}

These regulations establish minimum requirements specific to processing plants subject to federal jurisdiction for the safety of persons and the protection of property and the environment. 


\section{BILL C-9, AN ACT TO AMEND THE CANADIAN ENVIRONMENTAI. ASSESSMENT ACT ${ }^{81}$}

Bill C-9 (formerly Bill C-19) is the long-awaited result of the five-year review process into the Canadian Environmental Assessment Act. ${ }^{32}$ Bill C-9, among other things, proposes to establish a federal environmental assessment co-ordinator for projects that are required to undergo screening or comprehensive study assessments. Class screening reports may now be used to replace project-specific assessments.

Also provided for is the creation of the Canadian Environmental Assessment Registry, which is intended to enhance public access to environmental assessment information respecting specific projects. In addition, the comprehensive study process will be amended to prevent a second environmental assessment of a project by way of panel review. Participant funding administered by the Canadian Environmental Assessment Agency will also be available to projects requiring comprehensive study assessments.

On 28 January 2003, amendments proposed by the Standing Committee on Environment and Sustainable Development were reported to the House of Commons. Bill C-9 is awaiting final reading.

\section{YUKON SURFACE RIGHTS BOARD ACT $7^{83}$}

The land claims agreement entered into by the Ta'an Kwach'an on 13 January 2002 was added to Part I, Schedule I of the Yukon Surface Rights Board Act. ${ }^{84}$ This enables the aforementioned First Nation to make application to the Surface Rights Board under the Yukon Surface Rights Board Act respecting issues of right of access, including compensation.

\section{NUNAVUT WATERS AND NUNAVUT SURFACE RIGITS TRIBUNAL ACT ${ }^{85}$}

The Nunavut Waters and Nunavut Surface Rights Tribunal Act (Nunavut Act) came into force on 30 April 2002 (except for ss. 171(2) to (4), 172, 173(1),(2) and 174(1), which were deemed to have come into effect on 9 July 1996) and implemented provisions of the 1993 Nunavut Lands Claim Agreement. Among other things, the Nunavut Act created the Nunavut Water Board (NWB) and the Nunavut Surface Tribunal (NST) to regulate water use and land access disputes in Nunavut.

The NWB is responsible for licensing persons who use or who deposit waste in Nunavut waters. An applicant or licensee may also apply to the NWB to expropriate, in accordance with the Expropriation $A c t,{ }^{86}$ land or an interest in land in Nunavut, provided that the Minister, on the NWB's recommendation, is satisfied that certain conditions, including the public interest criterion, have been met. 
The NST is responsible for regulating land access issues in Nunavut. The NST has jurisdiction to resolve a number of matters, including the following disputes: those between Inuit and persons wishing to access Inuit land; those between persons who occupy Crown lands and persons holding subsurface rights who wish to access Crown lands; and those concerning loss to Inuit as a result of damage to wildlife by development activities.

In addition, the Nunavut Act consequentially amended various acts, including the Canada Oil and Gas Operations $A \mathrm{Ar}^{87}$ and the Mackenzie Valley Resource Management Act. ${ }^{88}$

\section{B. AlberTA}

\section{ALBERTA ENERGY \& UTILITIES BOARD ACT ${ }^{89}$}

The Alberta Energy and Utilities Board Act was amended by the Security Management Statutes Amendment $A c t, 2002^{90}$ to permit the AEUB to make regulations with respect to "terrorist activity." As a result, the AEUB is now entitled to make regulations with respect to the shutdown of, security measures to be adopted at and access to information regarding certain energy generation or transmission facilities. The Electric Utilities $A c t^{91}$ was similarly amended.

\section{ENVIRONMENTAL PROTECTION AND ENHANCEMENT ACT $7^{02}$}

The Administrative Penalties and Related Matters Statutes Amendment Act, 2002 33 amended the EPEA to permit the Director to cancel or suspend an approval or registration or to cancel or refuse a personal information number to a holder or applicant who is indebted to the Crown. This statute also modified the penalty scheme of the EPEA.

\section{ADMINISTRATIVE PENALTY REGULATION ${ }^{\text {94 }}$}

This regulation came into force on 12 February 2003 and repealed the former Administrative Penalty Regulation. ${ }^{95}$ It sets forth the provisions in respect of which a notice of administrative penalty may be given under $\mathrm{s} .237$ of the $E P E A^{96}$ and establishes criteria to determine the administrative penalty payable for each contravention that occurs.

R.S.C. 1985 , c. $0-7$.

S.C. 1998, c. 25.

Supra note 51.

S.A. 2002, c. 32 ,

R.S.A. 2000 , c. E-5.1

Supra note 70.

S.A. 2002 , c. 4.

Alta. Reg. 23/2003.

Alta. Reg. 143/95.

Supra note 70. 


\section{OIL AND GAS CONSERVATION REGULATIONS}

During 2002, the Oil and Gas Conservation Regulations (the Regulation) were amended as follows:

(a) The AEUB was empowered to require a security deposit from a licensee or an applicant for a transfer of a license in certain situations;,

(b) The administration fees applicable to individual wells and to operators of oil sands projects and provisions pertaining to the annual adjustment were amended, ${ }^{99}$

(c) Part 16.5 of the Regulation pertaining to the Orphan Fund was replaced; ${ }^{100}$ and

(d) A procedure for serving and paying notices of garnishment pursuant to $\mathrm{s}$. 103 of the $O G C A^{101}$ was established and a Form of Garnishment was added to the Regulation. ${ }^{102}$

\section{GAS UTILITIES STATUTES AMENDMENT ACT, 2003 ${ }^{103}$}

On 4 March 2003, the government introduced the Gas Uitities $A c t$, the intention of which is to improve the ability of natural gas consumers in Alberta served by major utility companies to buy natural gas from the supplier of their choice. Overall, the changes mandated by this legislation are intended to increase retail competition by providing a more equal footing for natural gas retailers and utility companies, aligning the retail natural gas and electricity markets to permit both commodities to be marketed together and enabling firms other than utility companies to provide regulated gas supply service to consumers.

Bill 19 proposes amendments to the Gas Utilities $A c t,{ }^{104}$ the Gas Distribution $A C l^{105}$ and the Rural Utilities Act. ${ }^{106}$

The legislation will implement rules for companies other than natural gas utilities to provide gas supply service at rates regulated by the AEUB; providers of such regulated natural gas supply service will be called default supply providers. The rates for such regulated natural gas supply will be based on a flow-through of Alberta spot prices, similar to gas cost recovery rates at the present time.

Consumers who buy natural gas from retailers will receive a single utility bill for both gas supply and delivery costs, rather than two separate bills as occurs under the current practice.

Bill 19, Gas Uitities Statutes Amendment Act. 2003, 3rd Scss., 25th Leg., Alberta, 2003 (assented to 27 March 2003), S.A. 2003, c. 5 [Gas Uilities Act].

R.S.A. 2000 , c. G-5.

R.S.A. 2000 , c. G-3.

R.S.A. 2000, c. R-21. 
Natural gas utilities will continue to have the exclusive right to provide regulated natural gas delivery service, but companies with affiliated retailers will be subject to a code of conduct governing the sharing of information, facilities and staff between the two entities.

\section{BRItish Columbia}

\section{ENVIRONMENTAL ASSESSMENT ACT ${ }^{107}$ AND RELATED REGULATIONS}

On 20 December 2002, the old Environmental Assessment Act was repealed and the new $E A A$ came into force. ${ }^{108}$ Under the $E A A$, the Environmental Assessment Office is continued and a person undertaking a "reviewable project"109 is required to obtain an environmental assessment certificate from the Minister.

Under the $E A A$, a project may be designated "reviewable" by regulation or at the discretion of the Minister. The Executive Director or, at his or her option the Minister, has the discretion to determine whether an assessment is required with respect to any such reviewable project. If an assessment is ordered, the Executive Director or the Minister, as the case may be, has the authority to establish the scope and procedural rules to be applied during the assessment process, although this discretion is limited to some extent by certain regulations enacted under the $E A A$. Upon the conclusion of a hearing, the individual or panel responsible for the assessment will refer a recommendation to the Minister and the Minister shall determine if a certificate shall be issued. In the event that a person commits an offence under the $E A A$, it provides for penalties, including substantial fines and/or imprisonment.

Transitional provisions provide that activities which were substantially started before 20 December 2002, and which either satisfy certain conditions or are designated as exempt by the Transition Regulation, ${ }^{10}$ are not subject to the EAA.

\section{REGULATIONS ENACTED UNDER THE ENVIRONMENTAL ASSESSMENT ACT ${ }^{\prime \prime \prime}$}

In the course of implementing the $E A A$, the government of British Columbia has made several new regulations, frequently of a procedural nature. These include:

Reviewable Projects Regulation, ${ }^{112}$ which establishes criteria for the purpose of determining whether a project is "reviewable" for the purposes of the $E A A$. These criteria include project size, potential for adverse effects and industry type;

- Prescribed Time Limits Regulation, ${ }^{113}$ which prescribes certain time limits contemplated by the $E A A$; 
- Public Consultation Policy Regulation, ${ }^{114}$ which establishes general policies regarding public consultation and access to information during the $E A A$ assessment process; and

- Concurrent Approval Regulation, ${ }^{1 / 5}$ which sets forth policies and procedures to be followed during concurrent approval process contemplated by the $E A A$.

\section{PETROLEUMAND NATURAL GAS DRILLING LICENSE REGULATION 116}

The Petroleum and Natural Gas Drilling Licence Regulation was amended to permit the Minister to extend drilling licences for up to one year in certain situations.

\section{UTILITIES COMMISSION ACT ${ }^{117}$}

The definition of "public utility" contained in the Utilities Commission Act was amended by the Energy and Mines Statutes Amendment $A c t, 2003^{118}$ to include a person who enters into or is created by an agreement designated under s. 12(9) of the Hydro and Power Authority Act. ${ }^{119}$

\section{ENERGY RESOURCE REMOVAL EXEMPTIONS REGULATION ${ }^{120}$}

The amendment ${ }^{121}$ to the Energy Resource Removal Exemptions Regulation adds natural gas and electricity to those items exempted from the requirement to obtain an energy removal certificate by $\mathbf{s} 1$.

\section{SaSkatchewan}

\section{SASKENERGY ACT}

The SaskEnergy Act was amended by the SaskEnergy Amendment Act, 2002, ${ }^{123}$ to include certain definitions and certain provisions pertaining to the operation of gas supply systems by SaskEnergy or by other persons. Additionally, provisions related to the appointment of directors of SaskEnergy and to the requirements for ministerial approval of property acquisitions exceeding a certain value by SaskEnergy were also amended.

\footnotetext{
B.C. Reg. 373/2002.

B.C. Reg. $371 / 2002$.

B.C. Reg. $111 / 2002$.

R.S.B.C. 1996, c. 473.

S.B.C. 2003, c. I.

R.S.B.C. 1996, c. 212.

B.C. Reg. 46/2003

B.C. Reg. $385 / 80$.

S.S. 1992 , c. S-35.I.

12) S.S. 2002, c. 58 .
} 


\section{E. Guidelines, POlicies ANd Directives}

\section{National. EnERgy BoARD}

a. Guidance Notes for the Onshore Pipeline Regulations, 1999 - Amendment $1^{124}$

Amendments to the Guidance Notes for the Onshore Pipeline Regulations, $1999^{123}$ have been proposed by the NEB. These are intended to provide additional explanation of specific sections of the regulations and to provide examples of methods that could be used to achieve compliance.

Additional amendments have also been proposed to the regulations pertaining to the process used by the NEB to consider decommissioning applications. ${ }^{126}$

b. National Energy Board Pipeline Crossing Regulations, Part II - Damage Prevention Regulations

On 29 May 2002, the NEB released $A$ Conceptual Draft of the Proposed National Energy Board Damage Prevention Regulations \& Guidance Notes ${ }^{127}$ intended to regulate activities on or adjacent to pipeline rights-of-way under NEB jurisdiction in the interests of the safety of the public and of company employees and the protection of property and the environment.

c. Offshore Waste Treatment Guidelines ${ }^{128}$

The Offshore Waste Treatment Guidelines are published by the Canada-Newfoundland Offshore Petroleum Board, the Canada-Nova Scotia Offshore Petroleum Board and the NEB. These describe minimum standards for the treatment and/or disposal of wastes associated with routine operations of drilling and production installations in offshore Canada. A multistakeholder working group undertook a review of the existing Guidelines, last published in 1996. A draft of the revised Guidelines was issued in February 2002 for public comment and was further modified based on comments received. In August 2002, the three Boards approved the final guidelines.

\section{d. Guidelines for Filing Requirements, 1995}

In October 2002, the NEB launched a project to review and revise its Guidelines for Filing Requirements. ${ }^{129}$ The objectives provide clear direction about the information required for applications, improve cycle times and improve communication with stakeholders.

124

125

126

(20 January 2003) (NEB).

S.O.R./99-294.

Letler from NEB to All Pipeline Companies under National Energy Board Jurisdiction (5 February 2003) (re Proposed Amendment to the Onshore Pipeline Regulations, 1999 - Decommissioning of Pipelines and Related Facilitics) (NEB).

(29 May 2002) (NEB).

Notice of Publication of Revised Offshore Waste Treatment Guidelines (21 August 2002), online: NEB <inww.neb.gc.ca/pubs/ActsRegs/owigl_e.htm>.

Letter from NEB to Interested Parties (4 November 2002) (Guidelines for Filing Requirements (GFR)), online: NEB <www.neb.gc.ca/pubs/ActsRegs/020927gfreview_e.pdfs. 


\section{e. Dispute Resolution Program}

In September 2002, the NEB issued a discussion paper ${ }^{130}$ for comment outlining its proposed Appropriate Dispute Resolution program. The document described options for settling disputes as an addition to the NEB's traditional regulatory process. Comments on the program were due on 5 November 2002.

\section{ALBERTA ENERGY UTILITIES BOARD POLICY MATTERS}

a. Revised Negotiated Setllement Guidelines Tolls, Tariffs, and Terms and Conditions of Service ${ }^{131}$

On 4 February 2003, the AEUB issued its Revised Negotiated Settlement Guidelines, which are most often used amongst stakeholders involved in utility rate issues. The Guidelines established ground rules for the conduct of the settlement process. The revisions outlined new requirements which require initial AEUB approval of the proposed settlement process, including the issues to be negotiated, information to be provided to the AEUB at the front end of the process and timing of the settlement process. The guidelines also set new requirements for AEUB staff to act as observers during the settlement process.

\section{b. EUB Requirements for Submission of Data for Solution Gas Flaring and Venting Evaluations ${ }^{132}$}

On 16 October 2002, the AEUB issued this Interim Directive, which provides new requirements relating to the electronic filing of volumetric information and well status changes. Monthly reporting requirements as set out in s. 12 of the Oil and Gas Conservation Regulations ${ }^{133}$ may now be filed electronically. The Interim Directive outlines how the new requirements must be electronically filed to the AEUB.

\section{c. Performance Presentations for In Situ Oil Sands Schemes ${ }^{134}$}

On 20 December 2002, an Interim Directive was issued by the AEUB to all in situ oil sand operators that implements a new and annual process for reporting the performance of commercial and experimental schemes. Presentations to the AEUB and its staff are now required and are intended to keep the AEUB appraised of the developments and depletion strategies within all approved in situ oils and schemes, to ensure that sufficient and reliable data are being gathered on in situ oils and schemes and to monitor ongoing compliance with approval and regulatory requirements. 


\section{d. Revised EUB Guide 64: Facility Inspection Manual}

On 4 July 2002, ${ }^{135}$ the AEUB revised its Guide 64: Facility Inspection Manual ${ }^{136}$ concerning satisfactory and minor/major/serious unsatisfactory inspection results as well as consequences for non-compliance with the AEUB's enforcement process outlined in EUB Enforcement Process, Generic Enforcement Ladder, and Field Surveillance Enforcement Ladder. ${ }^{137}$ The intent of the revised guide is to ensure that inspection criteria used by the AEUB are consistent throughout the province. In addition, the AEUB has documented a process to clarify regulatory requirements for off-site hydrogen sulphide odour remissions.

\section{e. EUB Proposes Amendments to Guide $31 \mathrm{~A}$ and $31 \mathrm{~B}$ to Address Appropriate Treatment of Costs with Respect to Review Requests ${ }^{138}$}

On 8 October 2002, the AEUB proposed amendments to Guide 3/A: Guidelines for Energy Cost Claims ${ }^{139}$ and Guide 3/B: Guidelines for Utility Cost Claims ${ }^{140}$ to address appropriate treatment of costs with respect to review requests. The AEUB has broad discretion to make cost awards pursuant to 5.28 of the Energy Resources Conservation Act ${ }^{141}$ and 5.68 of the Public Utilities Board Act. ${ }^{142}$ An emerging issue arose in respect of whether the AEUB should make awards of costs when review applications are dismissed on the preliminary question of whether the matter at hand should be reviewed, and whether there is reason to believe that the order, decision, or direction should be rescinded or varied. Where an industry applicant requests a review and this is denied on the preliminary question, the AEUB has proposed that the industry applicant bear its own costs, as well as those costs incurred by any local intervener in relation to review. With respect to utility matters, if a utility files a review request that is dismissed on the preliminary question, the AEUB has proposed that the costs incurred by the utility and any interveners in that regard should be borne by the utility's shareholders and not by ratepayers.

\section{f. Recision of Interim Directive (ID) 2000-10: Retrospective}

Facility Licensing Program and Guide 68: Retrospective

Facility Licensing, October $2000^{143}$

On 22 October 2002, the AEUB rescinded Interim Directive 2000-10: Retrospective Facility Licensing Program ${ }^{144}$ and Guide 68: Retrospective Facility Licensing. ${ }^{145}$ Between 21 February 2001 and 22 October 2002, the AEUB had exercised discretion in accepting retrospective facility licensing applications. However, this grace period has now ended. Any

(4 July 2002), GB 2002-08 (AEUB).

2d ed., July 2002 (AEUB).

(8 June 1999), 11 99-04 (AEUB).

(8 Oetober 2002), GB 2002-15 (AEUB).

June 2001 (AEUB).

June 2001 (AEUB).

R.S.A. 2000 , c. E-10.

R.S.A. 2000 , c. P-45.

(22 October 2002), GB 2002-16 (AEUB).

(24 October 2000), ID 2000-10 (AEUB).

October 2000 (AEUB). 
existing facilities that require licensing must now be applied for in accordance Guide $56^{146}$ and must satisfy all application requirements, including public consultation.

\section{g. Electronic Application Submission: Phase $1^{147}$}

On 25 October 2002, the AEUB announced that by the spring of 2003, applicants wishing to submit applications made pursuant to Guide 28: Applications for Power Plants. Substations, and Transmission Lines, ${ }^{148}$ Guide 65: Resources Applications for Conventional Oil and Gas Reservoirs ${ }^{149}$ and Well Licence Applications under Guide 56 will be able to do so by way of electronic submission. This is the next phase of the AEUB's integrated application process, which is a multi-year project to provide stakeholders with electronic business solutions for all of their AEUB application requirements.

h. I) Isolation Packer Testing, Reporting and Repair Requirements

2) Surface Casing Vent Flow/Gas Migration Testing, Reporting. and Repair Requirements 3) Casing Failure Reporting and Repair Requirements ${ }^{150}$

On 30 January 2003, this Interim Directive was issued to all oil and gas operators concerning isolation packer testing reporting and repair requirements, surface casing vent flows, gas migration and casing failure reporting and repair requirements. This replaces the requirements outlined in Isolation Packer Tests Testing and Reporting Requirements, ${ }^{\text {st }}$ Surface Casing Vent Flow/Gas Migration (SCVF/GM) Testing and Repair Requirements ${ }^{152}$ and Casing Failure Reporting. ${ }^{153}$

\section{i. EUB Guide 29 on Applications and the Hearing Process Now Available $e^{154}$}

On 27 January 2003, the AEUB published its Guide 29: Energy and Uitity and Development Applications and the Hearing Process ${ }^{155}$ which provides the general pubic with a step by step explanation of the application and hearing process.

j. Licensee Liability Rating (LLR) Program: 2003 Industry

Parameters and Clarification of Requirements ${ }^{156}$

On 28 January 2003, the AEUB provided clarifications to the licensee liability rating program requirements as outlined in Interim Directive 2001-8: Revised Licensee Liability Rating (LLR) Program and Energy Development Licence Transfer Requirements. ${ }^{157}$ The

Supra note 60 .

(25 October 2002), GB 2002-17 (AEUB).

September 2002 (AEUB).

June 2000 (AEUB).

(30 January 2003), 1D 2003-0I (AEUB).

(20 September 1994), Informational Letter $94-18$ (ERCB).

(16 February 1999), ID 99-3 (AEUB).

(18 September 1989), Informational Letter 89-19 (LRCB).

(27 January 2003), GB 2003-02 (AEUB).

(January 2003), GB 2003-03 (AEUB).

(28 January 2003), GB 2003-03 (AEUB).

(4 December 2001), ID 2001-8 (AEUB). 
clarifications included the method by which production is electronically reported to the AEUB, deemed liability for wells located on a multi-well pad, and clarifications to the Licensee Liability Rating Enforcement Ladder as outlined in IL 99-04. ${ }^{138}$

\section{k. Revised EUB Guide 46: Production Audit Handbook $k^{159}$}

On 4 February 2003, the AEUB revised Guide 46: Production Audit Handbook. ${ }^{160}$ The intent of Guide 46 is to ensure that auditing criteria used by the AEUB are consistently applied and that the facility licensee/operator is informed of the auditing requirements and protocol. The changes made from the previous addition of Guide 46 include enhancement and clarification of audit selection criteria, audit procedures and protocol.

1. Draft Interim Directive (ID) 2003-XX: Requirements for

Site-Specific Liability Assessments in Support of the EUB's

Liability Management Programs Available on EUB

Web Site for Siakeholder Comment ${ }^{161}$

On 14 March 2003, the AEUB issued a draft Interim Directive, which addresses the rules and guidelines for estimating site-specific suspension, abandonment and reclamation costs of energy development projects. Licensees may voluntarily initiate these site-specific liability assessments or they may be required by the AEUB in accordance with ID 2001-8. ${ }^{162}$

m. Draft Guide 56 (2003) Available on EUB Web Site for Stakeholder Comment ${ }^{163}$

On 26 March 2003, the AEUB announced proposed amendments to Guide 56: Energy Development Applications and Schedules. ${ }^{164}$ Substantive changes are proposed to Guide 56 and affect ss. 1 through 7 inclusive.

\section{n. Claims for Costs in Proceedings Before the EUB Commercial Interests ${ }^{165}$}

On 1 April 2003, the AEUB announced its intention to make an amendment to Part 5 of its Rules of Practice ${ }^{166}$ so that unless otherwise directed by the AEUB, a commercial participant in utilities proceedings would not be eligible to recover the costs of its participation. If made, the impact of such a change will significantly alter the method by which cost awards will be made in future utility proceedings.

Supra note 138.

(4 February 2003), GB 2003-04 (ALUB).

2d ed., January 2003 (AEUB) [Guide \$6].

(14 March 2003), GB 2003-07 (AEUB).

Supra note 157.

(26 March 2003), GB 2003-08 (AEUB).

(March 2003) (AEUB) (Draft) [Guide 56].

(1 April 2003), GB 2003.14 (AEUB).

Alta. Reg. 101/2001. 